\title{
The evaluation and interpretation of controls used in three commercially available quantification kits for forensic DNA analysis
}

Stephanie R. Schottke

Follow this and additional works at: https://researchrepository.wvu.edu/etd

\section{Recommended Citation}

Schottke, Stephanie R., "The evaluation and interpretation of controls used in three commercially available quantification kits for forensic DNA analysis" (2016). Graduate Theses, Dissertations, and Problem Reports. 6586.

https://researchrepository.wvu.edu/etd/6586

This Thesis is protected by copyright and/or related rights. It has been brought to you by the The Research Repository @ WVU with permission from the rights-holder(s). You are free to use this Thesis in any way that is permitted by the copyright and related rights legislation that applies to your use. For other uses you must obtain permission from the rights-holder(s) directly, unless additional rights are indicated by a Creative Commons license in the record and/ or on the work itself. This Thesis has been accepted for inclusion in WVU Graduate Theses, Dissertations, and Problem Reports collection by an authorized administrator of The Research Repository @ WVU. For more information, please contact researchrepository@mail.wvu.edu. 


\title{
The evaluation and interpretation of controls used in three commercially available quantification kits for forensic DNA analysis.
}

\author{
Stephanie R. Schottke, B.S
}

\author{
Thesis submitted \\ to the Eberly College of Arts and Sciences \\ at West Virginia University
}

in partial fulfillment of the requirements for the degree of

Master of Science in

Forensic and Investigative Science

Keith Morris Ph.D., Chair

Clif Bishop Ph.D.

Tina Moroose M.S.

Department of Forensic and Investigative Science

Morgantown, West Virginia 2016

Keywords: DNA, quantification, NIST SRM 2372

Copyright 2016 Stephanie R. Schottke 


\title{
ABSTRACT
}

\section{The evaluation and interpretation of controls used in three commercially available quantification kits for forensic DNA analysis.}

\author{
Stephanie R. Schottke, B.S.
}

This research presented an idea to aid crime laboratories in the selection of the best quantification method for use in DNA analysis in their laboratory. The goal of this research was to evaluate the suitability of using an external reference standard, the NIST SRM 2372 Human Quantitation Standard, to increase the quality of quantification results of human DNA analysis in commercially available kits. Additionally, the DNA standard included with the commercial kit, used for developing a standard curve, was evaluated for accuracy and stability beyond the recommended time frame. The commercial quantification kits tested were: Quantifiler ${ }^{\circledR}$ Trio DNA Quantification Kit (Applied Biosystems ${ }^{\mathrm{TM}}$, Life Technologies), Plexor® HY System (Promega Corporation), and Investigator ${ }^{\circledR}$ Quantiplex HYres (Qiagen). It was found that generally the concentration of the NIST SRM 2372 was not accurately quantifying in all three quantification kits. Furthermore, it was found that each standard curve dilution series varied in accuracy, as well as stability. 


\section{Table of Contents}

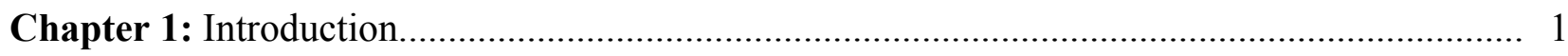

Chapter 2: Background and History of Quantification Methods............................. 2

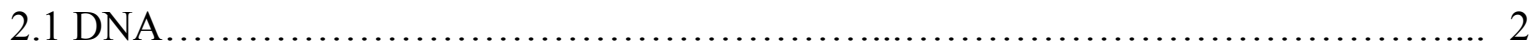

2.2 DNA Isolation/ Purification....................................................... 4

2.3 DNA Quantification................................................................ 5

2.3.1 History of Quantification............................................ 5

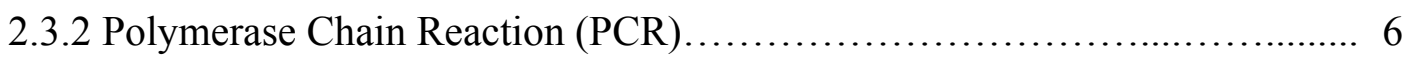

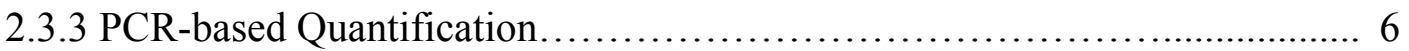

2.4 Commercially Available Kits...................................................... 8

2.4.1 Quantifiler ${ }^{\circledR}$ Trio DNA Quantification Kit............................... 9

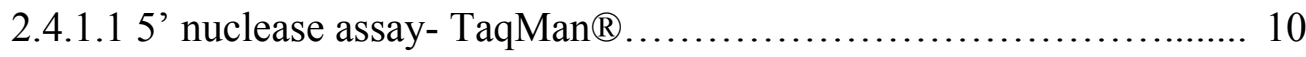

2.4.1.2 Quantifiler ${ }^{\circledR}$ Trio Analysis Parameters.......................... 13

2.4.2 Plexor ${ }^{\circledR}$ HY System.................................................. 13

2.4.2.1 Plexor ${ }^{\circledR}$ HY PCR Process....................................... 14

2.4.2.2 Plexor ${ }^{\circledR}$ HY Analysis Parameters.................................. 14

2.4.3 Investigator ${ }^{\circledR}$ Quantiplex HYres............................................ 15

2.4.3.1 Scorpions ${ }^{\circledR}$ Primers.............................................. 15

2.4.3.2 Investigator ${ }^{\circledR}$ Quantiplex HYres Analysis Parameters.............. 16

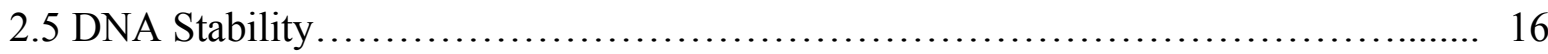

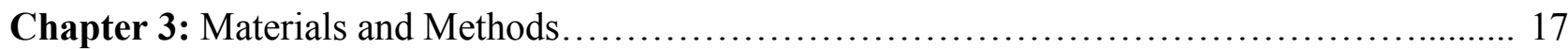

3.1 Serial Dilution Series using the NIST SRM 2372 Male DNA Component A.......... 17

3.2 Commercial Kit DNA Standards Evaluation of Performance and Stability............. 18

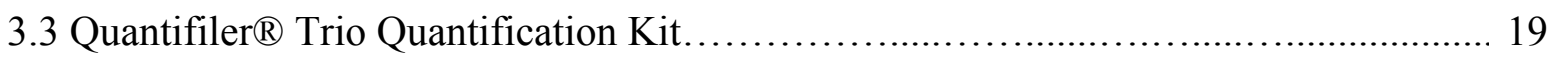

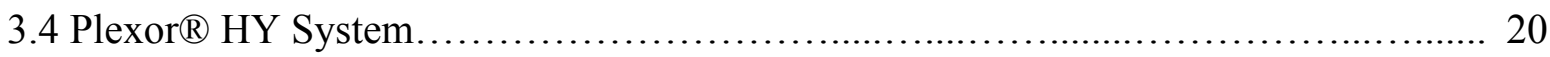

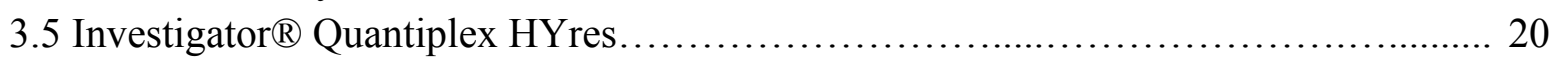

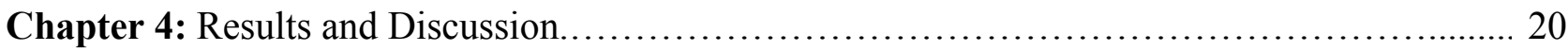

4.1 Serial Dilution Series using the NIST SRM 2372 Male DNA Component A.......... 20

4.2 Commercial Kit DNA Standard Evaluation of Performance and Stability............... 24

4.2.1 Quantifiler ${ }^{\circledR}$ Trio DNA Quantification Kit.................................. 24

4.2.2 Plexor ${ }^{\circledR}$ HY System........................................................ 28

4.2 .3 Investigator ${ }^{\circledR}$ Quantiplex HYres......................................... 31

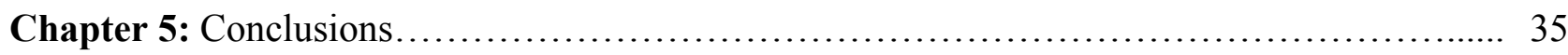

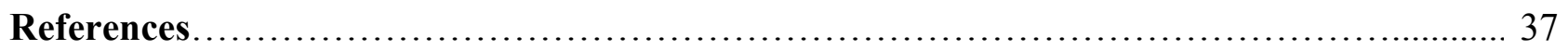




\section{Introduction}

The quantification of human nuclear DNA is an important step in forensic DNA analysis. When suspected biological evidence is collected at a crime scene it is likely that the sample collected contains more than human DNA. DNA isolation techniques not only isolate human DNA from the sample, but they also can isolate non-human DNA such as, bacterial, fungal, plant, or animal [1]. Accurate determination of the quantity of human DNA present in a sample is required for further DNA analysis techniques. Successful completion of capillary electrophoresis and short tandem repeat (STR) analysis starts with the accurate DNA quantification and serves as quality assurance for the isolation and purification of the sample. Additionally, the Federal Bureau of Investigation's (FBI) Quality Assurance Standards for Forensic DNA Testing Laboratories (Standard 9.3) states that a laboratory should have and follow a procedure for human DNA quantification [2].

The National Institute of Standards and Technology (NIST) created a Human Quantitation Standard (SRM 2372), which has been determined to be a stable, monitored standard that could reduce within- and among-laboratory variability [3]. The SRM 2372 can be utilized as standard DNA to determine a standard curve for quantification, and then be compared to unknown samples to determine the quantity of human DNA. In similar experiments with the Investigator® Quantiplex HYres kit, it was previously reported that the SRM 2372 was underestimated at lower dilutions of 5.24, 0.524, and 0.0524ng/uL [4].

Further, commercial quantification kits from various vendors have been developed to determine the amount of human DNA in a sample. These kits contain all the components to quantify DNA and they also include a standard DNA solution. This DNA standard is serially diluted to generate a standard curve to compare unknown quantities of DNA. The commercial kits provide a recommendation to prepare each standard DNA dilution series fresh, each time before analysis, and recommend a length of time for storage. This is due to DNA having the potential to form aggregates, and the tendency to bind to the plastic tubes it is being stored in [5] [6].

The specific project goals of this research study was to evaluate the suitability of using the standard reference material (SRM) as an external standard of comparison to determine the quality of quantitative results of human DNA analysis in commercially available kits. Additionally, the DNA standard included with the commercial kit was evaluated for its quantity 
and stability, beyond the recommended time frame. In the pursuit of these goals, the following objectives were tested:

1. Evaluate the performance of the NIST SRM 2372- Human DNA Quantitation Standard and

2. Evaluate the performance and stability of the DNA standard solution included in three commercially available kits.

a. Quantifiler@ Trio DNA Quantification Kit (Applied Biosystems ${ }^{\mathrm{TM}}$, Life Technologies)

b. Plexor® HY System (Promega Corporation)

c. Investigator $\AA$ Quantiplex HYres (Qiagen)

\section{Background and History of Quantification Methods}

\subsection{DNA}

DNA, or deoxyribonucleic acid is a molecule that contains the hereditary information for the cells of an organism; this genetic "programming" codes for the essential proteins needed for function of life. DNA is mostly found in the nucleus of the cell; however, there is some DNA found in the mitochondria of a cell. DNA found in the nucleus is known as nuclear DNA (nDNA), and DNA in the mitochondria is mitochondrial DNA (mtDNA) [7]. Nuclear DNA is inherited from both the father and mother in separately reproducing organisms, while mitochondrial DNA is only inherited from the mother. In forensic DNA analysis, an individual's genetic profile can be obtained from specific regions (loci) in the nuclear DNA.

Human nuclear DNA consists of two long polynucleotide chains composed of four possible nucleotides wound together in a double helix structure. Nucleotides are composed of a five-carbon sugar (deoxyribose), a phosphate group, and a nitrogen-containing base. There are four possible bases; adenine (A), cytosine $(C)$, guanine $(G)$, or thymine $(T)$. Adenine is paired with thymine, and guanine is paired with cytosine. The nucleotides are linked to each other through an alternating sugar-phosphate "backbone" and the bases of the two complementary strands are linked by hydrogen bonds. The "backbone" created has 5 'phosphate at one end and a 3' hydroxyl group at the other end. The two polynucleotide chains (strands) are opposed to one another, connecting the 5' end of one strand to the other strand 3' end, which is called antiparallel. The strands bound together are considered complementary, as seen in Figure 1 [8]. 


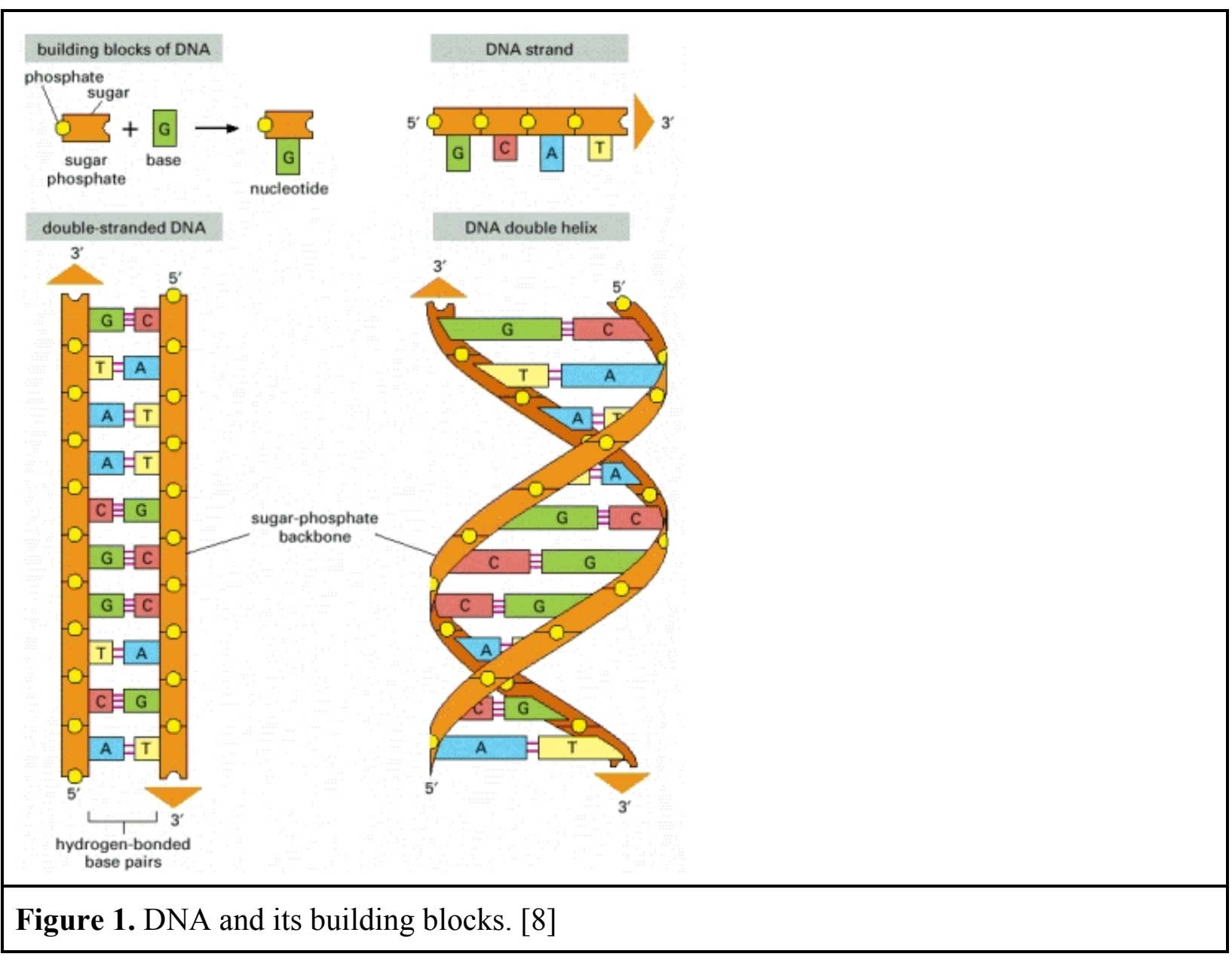

All of the DNA in a cell is known as the organism's genome; the genome in humans separated into 22 autosomal homologous chromosome pairs. An additional pair of chromosomes are called the sex chromosomes and is made up of X and Y chromosomes. Males normally have one $\mathrm{X}$ and $\mathrm{Y}$ chromosome, while females have two $\mathrm{X}$ chromosomes. A chromosome consists of a DNA molecule wrapped around proteins, called histones, and are compacted into an "X" like structure, with an exception for the Y chromosome in males, which is compacted into a "Y" shape. Twenty-three chromosomes are inherited from the mother and 23 from the father; those 23 chromosomes from each parent are similar to each other when they combine, but not identical in genetic material, making them homologous [8].

Chromosomes contain genes, which are the protein coding regions of the DNA. The genes are made up of introns and exons. Introns are regions of the gene that do not directly code for proteins, whereas exons do [9]. These genes are located in the same region on the chromosome called a locus in each individual. However, genes can be different in each person 
and these variations in genes are called alleles. If alleles in the homologous chromosome pair are identical it is called homozygous, and if they are different it is called heterozygous [10].

The cells in the human body have a ploidy, or the number of sets of chromosomes contained in the cell, associated with them. The chromosomal genetic material or autosomal material is considered to be in a diploid state. This means that the autosomal material contains all 46 chromosomes inside each nucleus. The gametes (sperm or egg) in the body are considered to be in a haploid state, which contain only half the chromosomes, 23 , in each nucleus because of meiosis. The combination of chromosomes leads to genetic differences between individuals, with an exception for identical twins. Usually, chromosomes do not combine in the same manner every time due to the laws of segregation and independent assortment during meiosis. In conception when egg and sperm combine the zygote becomes diploid [8] [10].

In the field of forensic DNA analysis, the characterization of alleles present a locus is called a genotype, and the combination of genotypes, at multiple loci is called a DNA profile. There are multiple processes to obtain a DNA profile. DNA has to be present and sufficient in integrity for processes, such as polymerase chain reaction (PCR) to work. The concentration of DNA present in a sample is measured in nanograms (ng) or nanograms per microliter (ng/uL). The target amount of DNA used for forensic DNA analysis is usually about 0.5 to 1 nanogram $[1]$.

\subsection{DNA Isolation/ Purification}

Cells are designed to protect the DNA from the environment within the nucleus. The process of isolating and purifying DNA from a biological sample is also known as DNA extraction in forensic DNA analysis. DNA contained in a sample should be separated from all other cellular material. If the cellular debris are not separated from the DNA it will interfere with the analysis results. Many different types of extraction methods have been developed because of the desire to study and use DNA from many cell types. Particular methods have been developed for extracting DNA from different types of cells, such as bone, hair, or blood [1].

There are many types of commercial kits containing a series of reagents, tubes, and substrates; however, they all follow similar principles. The first step involves lysing the cells to release the DNA, or rupturing open the cells and breaking down the cell membranes and other cellular material. A commonly used enzyme proteinase is added to break down proteins, and 
sodium dodecyl sulfate (SDS), a detergent, is added to lyse the membranes. After lysing, extraction techniques use either affinity or non-affinity methods of removing DNA from the solution.

In non-affinity methods, all other cellular material is removed leaving the DNA in solution; likewise, the affinity methods remove DNA from the solution. Examples of non-affinity methods are the organic extraction method or phenol- chloroform, salt precipitation, and chelex. Affinity methods can utilize glass-milk/silica gel, silica-coated magnetic beads, or antibodycoated magnetic beads. Nonetheless, with either type of method the DNA is separated from the other biological material, suspended into solution, and then can be used for further DNA analysis [11]

\subsection{DNA Quantification}

DNA quantification is of great importance for successful DNA analysis. When DNA is extracted from a biological sample, it is possible that DNA from other sources such as bacteria, plants, or animals is also extracted because DNA "acts" the same in all organisms. For human identification, the other sources of DNA are irrelevant and therefore the quantity of human DNA in the sample needs to be assessed. Furthermore, the FBI's quality assurance Standards for Forensic DNA Testing Laboratories states in Standard 9.3, “... laboratory shall have and follow a procedure for evaluating the quantity of the human DNA in the sample where possible" [2]. DNA amplification processes are reliant on the amount of DNA in a sample. Too much or too little DNA can affect later processes [1].

\subsubsection{History of Quantification}

There are commercial kits that contain the necessary reagents required to perform a DNA quantification today. However, prior methods of quantitation were not always species-specific, meaning that the technique could not differentiate between human DNA and other types of DNA. One method utilized is ultraviolet (UV) spectroscopy. This method reads the absorbance of the aromatic rings in the DNA strands [12]. Double stranded DNA (dsDNA) has an absorption of 260 nanometers $(\mathrm{nm})$. However, when strands are denatured (become single stranded (ssDNA)), the UV absorption ( $280 \mathrm{~nm}$ ) increases by $20-30 \%$. Thus, samples are analyzed at $260 \mathrm{~nm}$ and $280 \mathrm{~nm}$ and used an optical density ratio of $260 / 280$ is used to assess the purity of the 
sample and determine the amount of DNA present. If a sample has a ratio value of 1.8 to 2.0 the sample is considered pure; if lower than 1.8 there is a chance of a contaminating UV-absorbing substance, such as left over phenol-chloroform from an organic extraction [13].

Other methods used previously were yield gels and slot blots. Yield gels involved gel electrophoresis and staining with ethidium bromide. Ethidium bromide is an intercalating dye that binds between the DNA bases. A conformational change occurs when the ethidium bromide is incorporated and then it fluoresces when exposed to UV light [14]. The amount of fluorescence is proportional to the amount of DNA present in the sample. This process is not very sensitive, not specific, and consumes are large amount of the sample. Additionally, ethidium bromide is a carcinogenic material.

The slot blot method is a method that is specific for human and other primates. It uses a molecular probe that is 40 base pairs and can be found on chromosome 17. A chemiluminescent dye is attached to the probe and DNA is captured onto a nylon membrane. The DNA is washed with the probe/dye combination. The probe binds to the DNA and the amount of color a sample displayed from the dye was compared to a set of standards, or known quantities of DNA to estimate the amount of DNA present in a sample [15].

\subsubsection{Polymerase Chain Reaction (PCR)}

As the field of forensic DNA analysis advanced, the process of polymerase chain reaction (PCR) was invented by Kary Mullins. The PCR process involves cycles of denaturing, annealing, and extending DNA strands in a mixture of primers, polymerase, and deoxyribose nucleoside triphosphates (dNTPs), or free DNA bases. The cycles are regulated by temperature, and the process is similar to making paper copies on a copy machine. Primers are small DNA pieces that "flank" regions of DNA that are to be replicated. Polymerase is an enzyme that builds up the new DNA strands after reading a complementary DNA strand, and dNTPs are the nucleotide bases that the polymerase can use to build the new strands [1].

\subsubsection{PCR-based Quantification}

In Figure 2, each initial dsDNA strand is denatured into two ssDNA strands. Forward and reverse primers flank a human specific region of DNA and are annealed to the strands. The extension process allows the polymerase to move along the ssDNA strands and make them into 
dsDNA strands incorporating the dNTPs. Then this cycle is repeated many times, usually between 25-30 cycles, creating an exponential amount of copies of the DNA. Although methods can vary slightly, usually the denaturation occurs around $94^{\circ} \mathrm{C}$ for about 30 seconds to 1 minute. Annealing occurs around $60^{\circ} \mathrm{C}$ for 30 seconds to 1 minute, and extension occurs around $72^{\circ} \mathrm{C}$ for about 1 minute. Methods can also include an initial incubation period to denature the DNA strands and prepare the polymerase enzyme, as well as a final extension period to make sure all new strands have been completed [1].

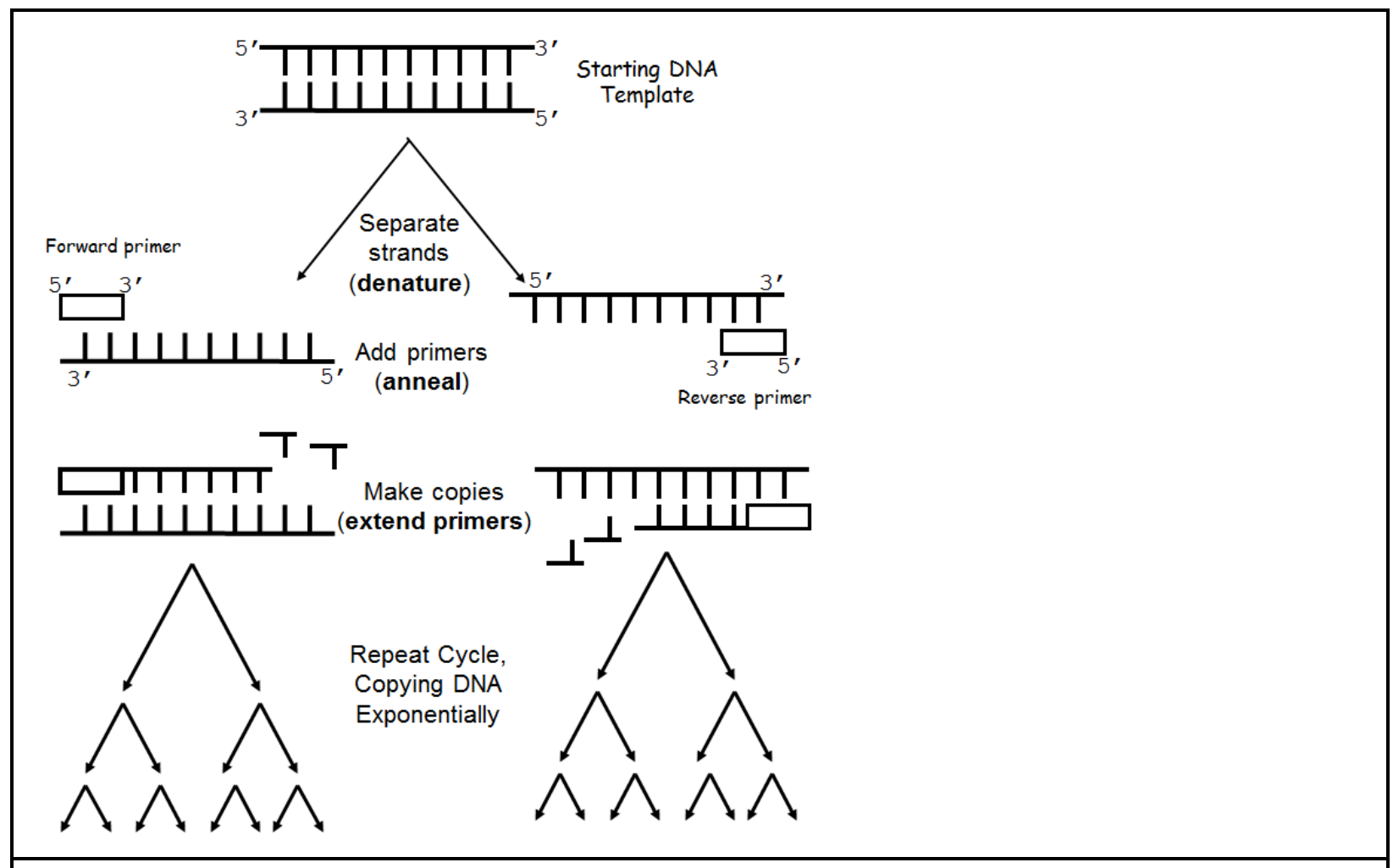

Figure 2. DNA amplification process with polymerase chain reaction. [1]

Using PCR technology the quantity of human DNA could be more accurately determined. One of the first methods to utilize a PCR system is the AluQuant quantitation system. This system uses an Alu sequence which is a highly repeated sequence found throughout the human genome, and an enzymatic reaction to produce light. The intensity of the light is measured and it is proportional to the amount of Alu regions amplified. The intensity of the light from the unknown samples are compared to a series of known DNA concentrations. Therefore, the quantity of DNA in the unknown samples could be determined [13]. 
End-point PCR is similar to this process; however, it uses a fluorescent intercalating dye such as SYBR Green and measures the fluorescence of the sample with the dye. More advanced, real-time quantitative PCR (qPCR) is the process of watching the amplification process in "realtime." Instruments that perform qPCR analyze the data collected after every amplification cycle. Quantitative PCR systems use human specific, and more recently, male specific primers and fluorescent reporter dyes to measure the quantity of DNA as it amplifies. Vendors that use qPCR have variations in the molecular process to enhance the results of the PCR [13].

When analyzing real-time PCR data there are three phases in the process; exponential, linear, and plateau amplification regions (Figure 3). The exponential growth phase is when PCR efficiency is at $100 \%$, and there is an abundance of all the reaction components. The linear phase is when the amplification efficiency begins to decrease because one or more of the components are decreasing, however copies of DNA are still being produced. The plateau phase is when the PCR reaction has stopped and one or more reaction components are gone. The threshold, a point at which a sample can be quantified, is determined by the instrument and is dependent on how much DNA template was present. The "Ct" value is the cycle at which the fluorescence of a sample crosses that threshold [16].

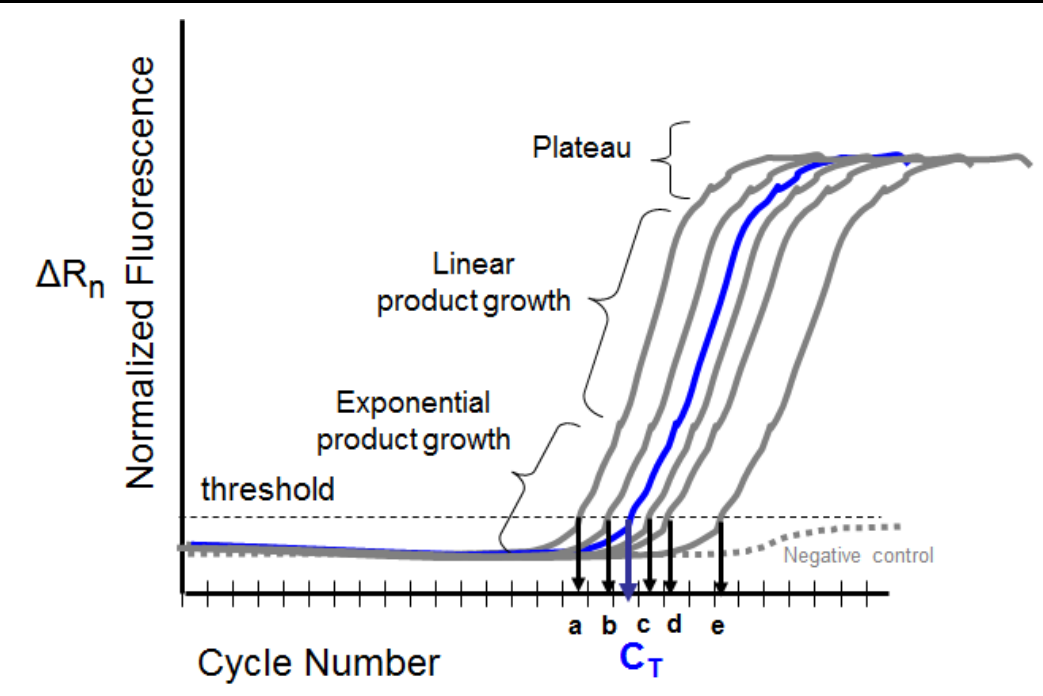

Figure 3. Real-time PCR phases of amplification. [1]

\subsection{Commercially Available Kits}

Quantification kits are commercially made for laboratories and contain all of the reagents, buffers, primers, reaction mixes, etc., that are required to complete the process. 
Additionally, they contain a DNA standard to create a standard curve, of which to evaluate the quantities of unknown samples. Each manufacturer has unique formulas and processes to quantify DNA. Likewise, the DNA standard used to determine the quantity of DNA in a sample are different for each kit. A laboratory must evaluate each kit for its sensitivity, specificity and accuracy to determine which would be suitable for their needs.

\subsubsection{Quantifiler ${ }^{\circledR}$ Trio DNA Quantification Kit (Applied Biosystems ${ }^{\mathrm{TM}}$, Life Technologies)}

The quantification kit from Applied Biosystems ${ }^{\mathrm{TM}}$, Quantifiler ${ }^{\circledR}$ Trio allows laboratories to obtain the quantity of total human and total male DNA at the same time. According to Life Technologies, this kit is highly accurate, sensitive, and specific. The kit can determine the ratio of human male to female DNA (1:4000 or greater), has a less than 1 pg/uL limit of detection, and is able to quantify concentrations from $0.005 \mathrm{ng} / \mathrm{uL}$ to greater than $50 \mathrm{ng} / \mathrm{uL}$. Quantifiler ${ }^{\circledR}$ Trio can predict the quality of the DNA sample, by using two autosomal regions, and results are obtained in about an hour. Importantly, the kit uses TaqMan ${ }^{\circledR}$ real-time PCR technology.

Quantifiler® Trio uses three human-specific target loci: a small autosomal (80 base pairs) multicopy diploid target, a large autosomal (214 base pairs) multicopy diploid target, and a small Y-chromosome haploid multicopy target ( 75 base pairs). The small autosomal target is the primary quantification target and the large autosomal target is mainly used to evaluate DNA degradation. It also includes a synthetic internal positive control (IPC) (130 base pairs). The positive control is designed to not bind to the human DNA. Each of these targets have a different dye/quencher combination to be read by the real-time PCR instrument. The DNA standard included in the kit is a pooled, human genomic, smaller molecular weight DNA. When using the Quantifiler ${ }^{\circledR}$ THP DNA Dilution Buffer the diluted standards can be stored in lowbinding microcentrifuge tubes for up to two weeks at $2-8^{\circ} \mathrm{C}$. Additionally, the kit also contains reaction and primer mix. The components of these reagents can be seen in Table 1 . The Quantifiler ${ }^{\circledR}$ Trio kit is designed for use with the Applied Biosystems ${ }^{\circledR} 7500$ Real-Time PCR System [17]. 


\begin{tabular}{|c|c|c|c|}
\hline Reagent & Contents & Quantity & Storage $^{\dagger}$ \\
\hline $\begin{array}{l}\text { Quantifiler }{ }^{\circledR} \text { THP PCR Reaction } \\
\text { Mix }\end{array}$ & $\begin{array}{l}\text { dNTPs, buffer, enzyme, Mustang } \\
\text { Purple }{ }^{\mathcal{O}} \text { Passive Reference } \\
\text { Standard, and stabilizers }\end{array}$ & 4 tubes, $1 \mathrm{~mL} /$ tube & $\begin{array}{l}-15 \text { to }-25^{\circ} \mathrm{C} \text { upon receipt } \\
2 \text { to } 8^{\circ} \mathrm{C} \text { after initial use } \\
\text { Store protected from light }\end{array}$ \\
\hline Quantifiler $^{\circledR}$ Trio Primer Mix & $\begin{array}{l}\text { Target-specific primers, } \text { ABY }^{\odot} \text {, } \\
\text { JUN }^{\odot} \text {. VIC } \\
\text { dye-labeled and } \text { FAM }^{\text {TM }} \\
\text { PCR Control (IPC) template }\end{array}$ & 4 tubes, $0.8 \mathrm{~mL} /$ tube & $\begin{array}{l}-15 \text { to }-25^{\circ} \mathrm{C} \text { upon receipt } \\
2 \text { to } 8^{\circ} \mathrm{C} \text { after initial use } \\
\text { Store protected from light }\end{array}$ \\
\hline $\begin{array}{l}\text { Quantifiler }{ }^{\circledR} \text { THP DNA Dilution } \\
\text { Buffer }\end{array}$ & $\begin{array}{l}\text { Genomic DNA Standard dilution } \\
\text { buffer }\end{array}$ & 2 tubes, $1.8 \mathrm{~mL} /$ tube & $\begin{array}{l}-15 \text { to }-25^{\circ} \mathrm{C} \text { upon receipt } \\
2 \text { to } 8^{\circ} \mathrm{C} \text { after initial use }\end{array}$ \\
\hline $\begin{array}{l}\text { Quantifiler }{ }^{\circledR} \text { THP DNA } \\
\text { Standard }\end{array}$ & $\begin{array}{l}\text { Genomic DNA Standard } \\
\text { formulated at } 100 \mathrm{ng} / \mu \mathrm{L} \text { to } \\
\text { generate standard curves }\end{array}$ & 1 tube, $0.12 \mathrm{~mL}$ & $\begin{array}{l}-15 \text { to }-25^{\circ} \mathrm{C} \text { upon receipt } \\
2 \text { to } 8^{\circ} \mathrm{C} \text { after initial use }\end{array}$ \\
\hline \multicolumn{4}{|l|}{ + See reagent labels for expiration dates } \\
\hline \multicolumn{4}{|c|}{$\begin{array}{l}\text { Table 1. The reagents, contents, quantity, and storage the reagents of the Quantifiler@ Tric } \\
\text { Kit. [17] }\end{array}$} \\
\hline
\end{tabular}

\subsubsection{5' nuclease assay- TaqMan ${ }^{\circledR}$}

A 5' nuclease assay using TaqMan ${ }^{\circledR}$ technology, is a process of DNA quantification by which a molecular probe bound with a fluorescent reporter dye and a non-fluorescent quencher dye are hybridized to a DNA strand. A fluorescent reporter dye is a dye that emits fluorescence that can be read by the real-time PCR instrument. The non-fluorescent quencher suppresses the fluorescence of the reporter dye by Förster-type energy transfer [18]. The probe is positioned on the DNA strand between the forward and reverse primers which flank the target region and direct DNA polymerase where to start and stop. As the polymerase moves down the DNA producing a new strand, the probe is cleaved from the DNA separating the fluorescent reporter dye from the non-fluorescent quencher. Thus, allowing the fluorescence of the reporter dye to be emitted. An increase in fluorescence signal is read as more cycles occur [1] [17].

A 5' nuclease assay process occurs every cycle during the amplification of DNA. The first step seen in Figure 4.a) is the polymerization of the TaqMan ${ }^{\circledR}$ probe to a complementary DNA sequence between the forward and reverse primer sites. "P" is the Taq DNA Polymerase enzyme, "R" is the reporter dye, and "NFQ" is the nonfluorescent quencher. Figure 4.b) is the strand displacement and at this point the reporter dye is still suppressed by the non-fluorescent quencher. It is important to note that the Taq DNA polymerase enzyme will only cleave probes 
that are hybridized to the target DNA and for that reason there is no nonspecific amplification to be detected [17].

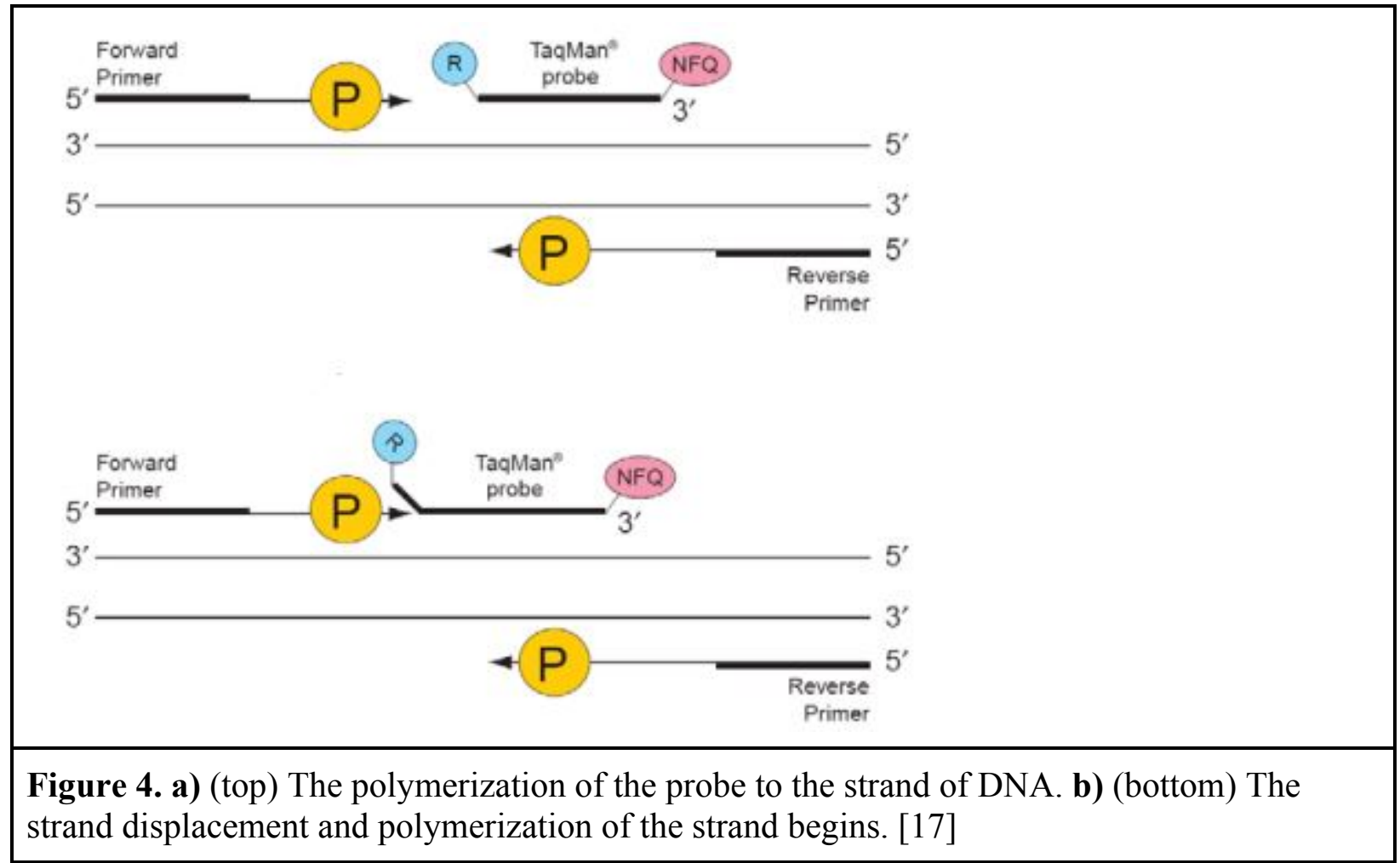

In Figure 5.a) the polymerization of the strand continues and the probe is cleaved from the strand. Here, the reporter dye will fluoresce because of the separation from the nonfluorescent quencher. In Figure 5.b) the 3' end of the TaqMan ${ }^{\circledR}$ probe is blocked by the nonfluorescent quencher so there is no extension of the probe into the new strand and the reporter dye is still emitting light. This process repeats on available DNA strands until one or more reaction components are used up. The fluorescence is read after each cycle by the Real-Time instrument [17]. 

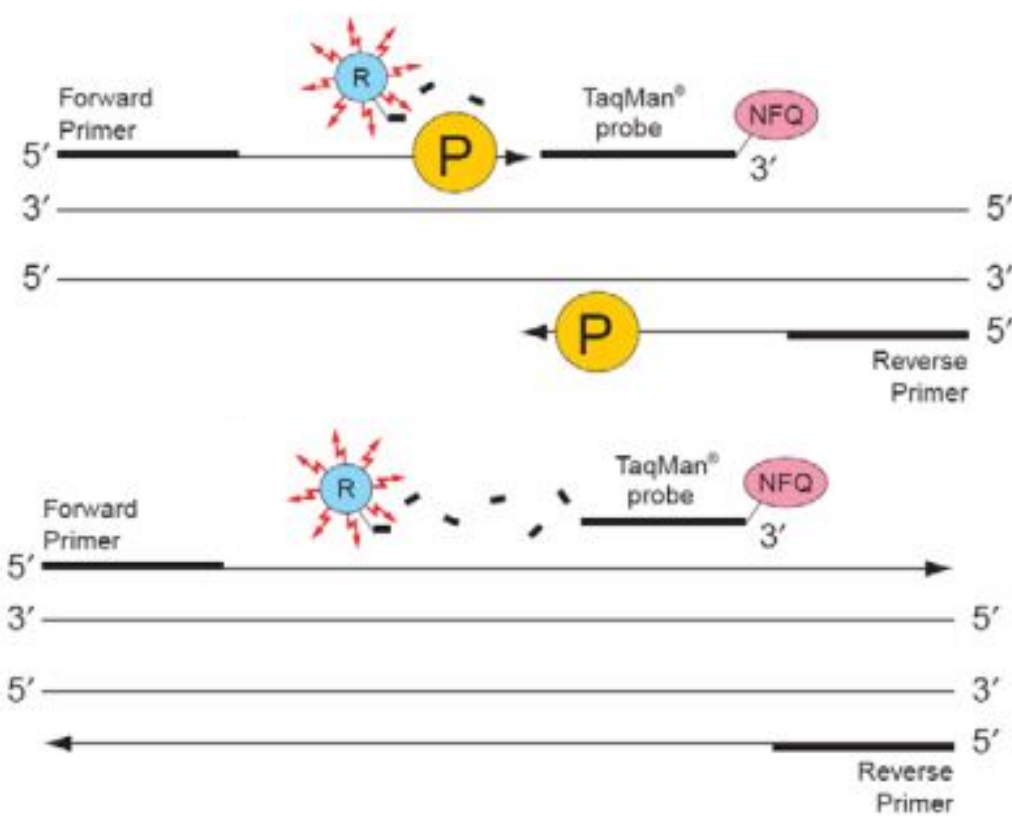

Figure 5. a) (top) The cleavage of the probe from the DNA strand. b) (bottom) The completion of polymerization of the DNA strand, however there is no extension of the probe because of non-fluorescent quencher blocking the 3 ' end. [17]

Table 2. contains the targets of the system, the length of the target, the ploidy, copy number, and the dye/quencher used for identification. The MGB probe either contains a FAM ${ }^{\mathrm{TM}}$ or VIC® reporter dye linked to the 5 ' end, and there is a minor groove binder (MGB) and nonfluorescent quencher (NFQ) at the 3' end. A minor groove binder increases the melting temperature without increasing the probe length [19]. The QSY probe either contains an ABY® or JUN® reporter dye linked to the 5' end, and there is a NFQ QSY ${ }^{\circledR}$ at the 3' end [17].

\begin{tabular}{l|c|c|c|c}
\hline \multicolumn{1}{c|}{ Target } & $\begin{array}{c}\text { Amplicon } \\
\text { length }\end{array}$ & Ploidy & Copy Number & Dye/Quencher \\
\hline Human Target, small autosomal & 80 bases & Diploid & multicopy & $\begin{array}{l}\text { VIC } \\
\text { MGB que with }\end{array}$ \\
\hline Human Target, large autosomal & 214 bases & Diploid & multicopy & $\begin{array}{l}\text { ABY dye with } \\
\text { QSY quencher }\end{array}$ \\
\hline Human Male Target ${ }^{\dagger}$ & 75 bases & Haploid & multicopy & $\begin{array}{l}\text { FAM }^{\text {TM }} \text { dye with } \\
\text { MGB quencher }\end{array}$ \\
\hline Internal PCR Control & 130 bases & NA & $\begin{array}{c}\text { Synthetic IPC } \\
\text { template is } \\
\text { included in the } \\
\text { primer mix }\end{array}$ & $\begin{array}{l}\text { JUN® dye with } \\
\text { QSY quencher }\end{array}$ \\
\hline
\end{tabular}

† Contained in the Quantifiler ${ }^{\oplus}$ Trio DNA Quantification Kit only

Table 2. Quantifiler ${ }^{\circledR}$ Trio Quantification Kit targets. [17] 


\subsubsection{Quantifiler® Trio Analysis Parameters}

There are various analysis parameters that should be met when using the Quantifiler ${ }^{\circledR}$ Trio kit in order to achieve more accurate results. The standard curve is evaluated using the equation: $\mathrm{C}_{\mathrm{T}}=\mathrm{m}[\log (\mathrm{Q} t \mathrm{y})]+\mathrm{b}$. The equation is the threshold of the standard dilutions versus the quantity of the standards.

The slope, or " $\mathrm{m}$ " has a different range of acceptable values for each target. The small autosomal target standard curve should have a slope in the range of -3.0 to -3.6 with an average of -3.3 . The large autosomal target standard curve should have a slope in the range of -3.1 to -3.7 with an average of -3.4. The male target should have a range of -3.0 to -3.6 with an average of 3.3 .

Each target's standard curve should have an $\mathrm{R}^{2} \geq 0.99$; the measure of the fit of the data points to the linear regression line. There will be variation in the " $b$ " or y-intercept of the graph depending on the experiment and other various factors. The kit claims to have a linear regression from $100 \mathrm{ng} / \mathrm{uL}$ to $5 \mathrm{pg} / \mathrm{uL}$, and a slope of -3.3 is equivalent to $100 \%$ efficiency of the PCR process [17].

\subsubsection{Plexor® HY System (Promega Corporation)}

The Plexor ${ }^{\circledR}$ HY System is a system that can quantify both total human and male DNA simultaneously. It can detect down to $6.4 \mathrm{pg}$ of DNA, contains an internal PCR control (IPC), and utilizes melt-curve analysis to control for potential false-negative or false-positive readings. The kit can be stored at room temperature because it involves hot-start chemistry. Plexor ${ }^{\circledR} \mathrm{HY}$ System is optimized for the Applied Biosystems 7500 and 7500 FAST Real-Time PCR systems, as well as Stratagene Mx3005P $®$ and Mx3000P $®$ qPCR systems. Additionally, Plexor ${ }^{\circledR}$ Analysis Software is available for free download through Promega Corporation. The kit includes: Master Mix, Primer/IPC Mix, Genomic DNA standard (50 ng/uL), and amplification grade water. Importantly, the DNA standard once thawed at $2-10^{\circ} \mathrm{C}$ should not be refrozen, and the number of freeze-thaw cycles should be minimized. It is not recommended to store diluted standards [5]. 


\subsubsection{Plexor® HY PCR Process}

The Plexor ${ }^{\circledR}$ technology uses modified nucleotide and it involves the use of two primers. The human primers amplify a 99 base pair target on chromosome 17, and the male primers amplify a 133 base pair region on the Y chromosome. One primer contains a modified nucleotide (iso-dC) and a 5' fluorescent reporter, while the other primer is unmodified. The reporter dye used on the human primers is fluorescein (FL), while the male primers use CAL Fluor® Orange 560 dye, and the internal positive control uses CAL Fluor® Red 610 dye. In the reaction mix there is a fluorescent quencher known as Dabcyl-iso-dGTP that is linked to the modified iso-dC nucleotide during the amplification process. When the quencher is in position it stops the fluorescence of the reporter; thereby, a decrease in fluorescence is accompanied by an increase in product. Figure 6. is a diagram of the real-time PCR process for the Plexor® HY technology. During the primer annealing and extension, the modified nucleotide (iso- $\mathrm{dC}$ ) and the fluorescent reporter are attached to the DNA strand. Then Taq polymerase moves along the template creating a new strand, thereby incorporating the Dabcyl-iso-dGTP quencher onto the strand, and the fluorescent reporter dye is quenched [5].

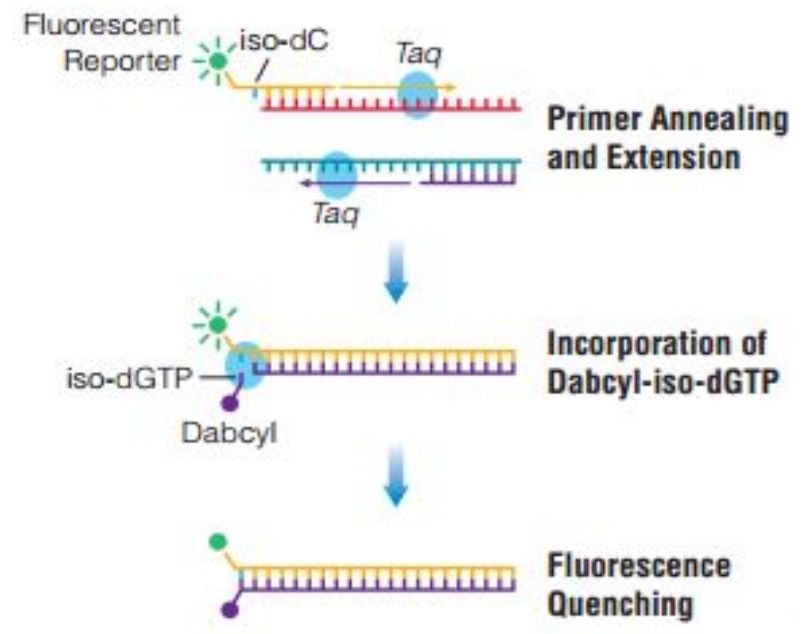

Figure 6. Diagram of Plexor® real-time PCR process. [5]

\subsubsection{Plexor® HY Analysis Parameters}

There are analysis parameters that should be met in order to achieve more accurate results with the Plexor ${ }^{\circledR}$ HY system. The standard curve is evaluated by the equation: $y=m x+b$. The " $x$ " 
is the $\log$ concentration of the standards and " $\mathrm{y}$ " is the $\mathrm{C}_{\mathrm{q}}$, or threshold. The human target standard curve should have a slope in the range of -3.2 to -4.0 with a $\mathrm{R}^{2} \geq 0.990$. The male target standard curve should have a slope in the range of -3.0 to -3.6 with a $R^{2} \geq 0.990$. A slope of -3.3 indicates $100 \%$ efficiency of the PCR process [5].

\subsubsection{Investigator ${ }^{\circledR}$ Quantiplex HYres (Qiagen)}

The Investigator ${ }^{\circledR}$ Quantiplex HYres is a commercial kit that can also perform simultaneous total human and male DNA quantification. It can quantify $50 \mathrm{ng} / \mathrm{uL}$ to about $0.5 \mathrm{pg} / \mathrm{uL}$, with a linear range between $20 \mathrm{ng} / \mathrm{uL}$ and $4.9 \mathrm{pg} / \mathrm{uL}$. For total human quantification, it amplifies a 146 base pair autosomal multi-copy target location utilizing the green FAM dye. Male DNA quantification is determined by a 129 base pair Y chromosome multi-copy region with a red Cy5 dye. Additionally, the kit contains a 200 base pair internal amplification control (IC) labeled with the yellow VIC dye. The kit contains: reaction mix, primer mix, nucleic acid dilution buffer, and control DNA (20 ng/uL). The reaction mix (Reaction Mix YQ) contains DNA polymerase and buffer formulated for high sensitivity and speed. The control DNA (Control DNA Z1) is a mixture of male and female DNA, where in $1 \mathrm{uL}$ it contains $20 \mathrm{ng}$ of human DNA and 12.3ng of male DNA. When the DNA standard is diluted with the QuantiTect Nucleic Acid Dilution Buffer it is stable for at least one week at $2-8^{\circ} \mathrm{C}$. It has also been streamlined for the Rotor-Gene Q, Applied Biosystems 7500 Real-Time PCR system for Human Identification, and Applied Biosystems 7500 and 7500 Fast Real-Time PCR systems [20].

\subsubsection{Scorpions® Primers}

The Quantiplex HYres system employs Scorpions ${ }^{\circledR}$ primers and fast PCR chemistry. The Scorpions ${ }^{\circledR}$ primers are a combination of a PCR primer linked to a probe that contains a fluorophore and a quencher. The fluorophore reacts with the quencher, which reduces fluorescence. Then, during the amplification process the fluorophore and quencher are separated. Therefore an increase in fluorescence indicates more product. Figure 7. diagrams how the Scorpions ${ }^{\circledR}$ primers function. The primer/probe combination is attached to the DNA strand. The loop contains a complementary strand of DNA to the target. When the probe is heated through the PCR process the probe unfolds. When the PCR process cools the complementary strand in 
the probe anneals to the DNA strand. The fluorophore and quencher are then separated and the fluorophore can emit light [20].

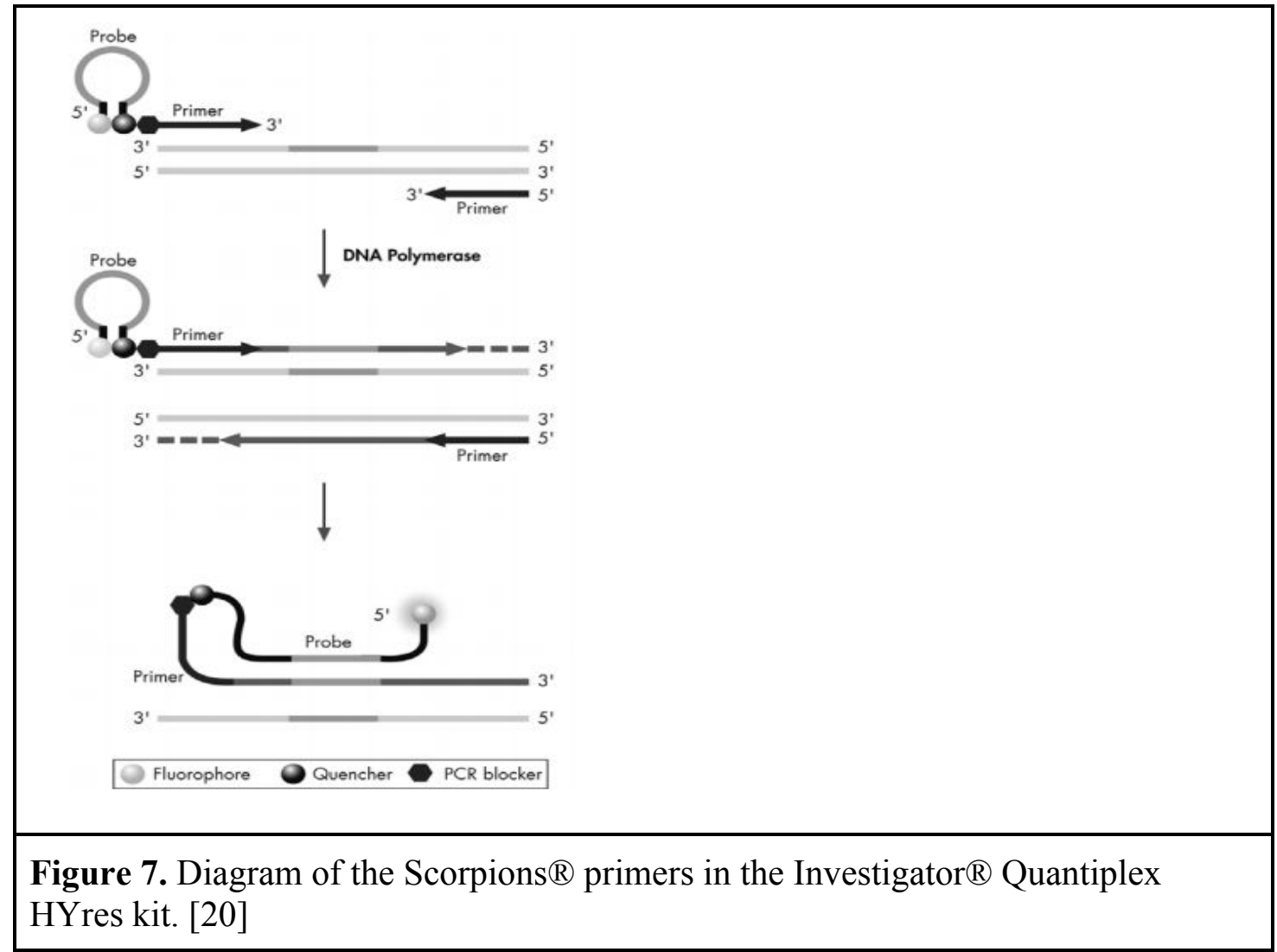

\subsubsection{Investigator ${ }^{\circledR}$ Quantiplex HYres Analysis Parameters}

There are parameters that should be met in order to achieve the best results using the Investigator ${ }^{\circledR}$ Quantiplex HYres kit. The standard curve is evaluated by the equation: $y=m x+b$. Where " $\mathrm{x}$ " is the log of the concentration of the standards and " $\mathrm{y}$ " is the $\mathrm{C}_{\mathrm{T}}$, or threshold. For both the human and male target standard curves, the slope should be in the range of -3.0 to -3.6. It should also have a $\mathrm{R}^{2} \geq 0.990$. A slope of -3.3 is considered to be a $100 \%$ efficient PCR process and the internal control (IC) should have a threshold of around 31. The kit claims to have standard curve detection range from $75 \mathrm{ng} / \mathrm{uL}$ to $0.5 \mathrm{pg} / \mathrm{uL}$, and is highly linear between $20 \mathrm{ng} / \mathrm{uL}$ and $4.9 \mathrm{pg} / \mathrm{uL}[20]$.

\subsection{DNA Stability}

The quality of a DNA sample can be decreased if the sample is not properly stored. Moist biological samples should be dried before packaging to prevent mold and bacteria growth that 
are inevitably mixed in with the sample. Samples should be kept dry and cold, again to prevent mold and bacteria growth. Bacteria and mold can contain DNases which are DNA digesting enzymes that will slowly break down the DNA present in a biological sample. A quality sample can be lost if not stored properly. DNA that has been extracted should be stored in water or buffer solution at $4^{\circ} \mathrm{C}$ or $-20^{\circ} \mathrm{C}$, or for long-term storage at $-70^{\circ} \mathrm{C}$ [21].

Extracted DNA is usually stored in some kind of polypropylene microcentrifuge tube. However, numerous studies have found that in long-term storage, DNA tends to bind to polypropylene microcentrifuge tubes. In one study, it was found polyallomer tubes, or specially designed low-binding polypropylene tubes had little DNA binding to the tube, but certain types of ordinary polypropylene tubes had almost a 75\% adsorption rate [22]. A NIST study in 2005 also found that in low quantities of DNA, a significant portion of the DNA binds to a polypropylene tube [23]. Additionally, another study found that certain chemicals in polypropylene/plastic additive tubes leach into the sample and have an absorbance between 220 and $260 \mathrm{~nm}$. This could interfere with quantitative UV absorbance results [24]. Many lowbinding tubes are polypropylene tubes that feature a special bonding of the polymer that reduces nucleic acid binding [25] [26] [27].

\section{Materials and Methods}

\subsection{Serial Dilution Series using the NIST SRM 2372 Male DNA Component A}

The NIST Standard Reference Material (SRM) 2372 Male DNA Component A (57ng/uL) was initially diluted 1:1 for the second standard, and then a 1:2 dilution series in low $\mathrm{TE}^{-4}$ buffer to the final concentration in regular microcentrifuge tubes (Corning ${ }^{\circledR} \operatorname{Costar} \AA$ cat $\# 3620$ ). Concentrations were: 57, 28.5, 7.125, 1.78, 0.4453, 0.113, 0.0278, 0.0069, and 0.0017ng/uL. Each concentration was replicated in triplicate in the sample plates for the Quantifiler ${ }^{\circledR}$ Trio, Plexor ${ }^{\circledR}$ HY, and Investigator ${ }^{\circledR}$ Quantiplex HYres kits to assess the accuracy of the results obtained by these kits. A new serial dilution was prepared for each kit type to avoid prolonged storage.

In RStudio ${ }^{\circledR}$ statistical analysis software, the log of the measured values obtained for each target were plotted against the log of the expected values at each dilution. This was done using the "xyplot" lattice function which produces bivariate scatterplots [28]. The summary outputs the residuals, coefficients, residual standard error, r-squared values, degrees of freedom, 
F-statistics, and the p-value. The focus for this experiment was on the r-squared values, degrees of freedom, and the p-value, to determine whether or not the measured values are statistically significantly different from the expected values. A p-value of less than 0.05 was considered significantly different.

\subsection{Commercial Kit DNA Standards Evaluation of Performance and Stability}

For the Quantifiler ${ }^{\circledR}$ Trio, Plexor ${ }^{\circledR}$ HY, and Investigator ${ }^{\circledR}$ Quantiplex HYres kits, the serial dilution series was followed as outlined in the protocol. The dilution concentrations are listed for each kit in Tables 3, 4, and 5. The serial dilution series for each kit was prepared once a week, for three weeks: week 1 being the oldest, week 3 being the newest. While a new series was being prepared, the old series was placed out at room temperature, to mimic usage of the series. In the kits where undiluted DNA is used as the first standard, enough volume was aliquoted. A series was created for both low-binding (Corning ${ }^{\circledR}$ Costar ${ }^{\circledR}$ cat\#3207) and regular (Corning ${ }^{\circledR}$ Costar ${ }^{\circledR}$ cat\#3620) microcentrifuge tubes for each week. Every sample was replicated in triplicate in the sample plates. This arrangement allows for the assessment of the stability of the standard DNA once diluted, as well as the evaluation of the usage of a low-binding or regular microcentrifuge tube to prevent DNA binding to the tube, increasing the stability of the dilution series.

For each dilution, the average for both the low binding and regular microcentrifuge tubes was calculated and plotted over three weeks' time. Additionally, a paired t-test for sample means was calculated to compare the low binding and regular microcentrifuge tubes for the entire three weeks with Microsoft Excel® data analysis software add-in. The t-stat and $\mathrm{P}(\mathrm{T}<=\mathrm{t})$ two tail values were recorded from the Excel ${ }^{\circledR}$ output. A p-value of less than 0.05 was considered significantly different. The difference of the means was also calculated and with the "Descriptive Statistics" the mean difference, standard deviation, and confidence level (95\%) values were obtained. 


\begin{tabular}{|c|c|c|c|}
\hline Standard & $\begin{array}{l}\text { Concentration } \\
{[(n g / \mu \mathrm{L}]}\end{array}$ & Example Volumes & $\begin{array}{l}\text { Dilution } \\
\text { Factor }\end{array}$ \\
\hline Std. 1 & 50.000 & $\begin{array}{l}10 \mu \mathrm{L}[100 \mathrm{ng} / \mu \mathrm{L} \text { stock }]+10 \mu \mathrm{L} \text { Quantifiler } \\
\text { THP DNA dilution buffer }\end{array}$ & $2 x$ \\
\hline Std. 2 & 5.000 & $\begin{array}{l}10 \mu \mathrm{L} \text { [Std. 1] + } \\
90 \mu \mathrm{L} \text { Quantifiler } @ \text { THP DNA dilution buffer }\end{array}$ & $10 x$ \\
\hline Std. 3 & 0.500 & $\begin{array}{l}10 \mu \mathrm{L} \text { [Std. 2] }+ \\
90 \mu \mathrm{L} \text { Quantifiler }{ }^{\oplus} \text { THP DNA dilution buffer }\end{array}$ & $10 x$ \\
\hline Std. 4 & 0.050 & $\begin{array}{l}10 \mu \mathrm{L} \text { [Std. 3] + } \\
90 \mu \mathrm{L} \text { Quantifiler }{ }^{\ominus} \text { THP DNA dilution buffer }\end{array}$ & $10 \times$ \\
\hline Std. 5 & 0.005 & $\begin{array}{l}10 \mu \mathrm{L} \text { [Std. } 4]+ \\
90 \mu \mathrm{L} \text { Quantifiler } \\
(\text { THP DNA dilution buffer }\end{array}$ & $10 \times$ \\
\hline
\end{tabular}

Table 3. The standard dilution series for Quantifiler®Trio DNA Quantification Kit. [17]

\begin{tabular}{|lcc}
\hline Concentration & Volume of DNA & Volume of TE-4 Buffer \\
\hline $50 \mathrm{ng} / \mu \mathrm{l}$ & Use undiluted DNA & $0 \mu \mathrm{l}$ \\
$10 \mathrm{ng} / \mu \mathrm{l}$ & $10 \mu \mathrm{l}$ of undiluted DNA & $40 \mu \mathrm{l}$ \\
$2 \mathrm{ng} / \mu \mathrm{l}$ & $10 \mu \mathrm{l}$ of $10 \mathrm{ng} / \mu \mathrm{l}$ dilution & $40 \mu \mathrm{l}$ \\
$0.4 \mathrm{ng} / \mu \mathrm{l}$ & $10 \mu \mathrm{l}$ of $2 \mathrm{ng} / \mu \mathrm{l}$ dilution & $40 \mu \mathrm{l}$ \\
$0.08 \mathrm{ng} / \mu \mathrm{l}$ & $10 \mu \mathrm{l}$ of $0.4 \mathrm{ng} / \mu \mathrm{l}$ dilution & $40 \mu \mathrm{l}$ \\
$0.016 \mathrm{ng} / \mu \mathrm{l}$ & $10 \mu \mathrm{l}$ of $0.08 \mathrm{ng} / \mu \mathrm{l}$ dilution & $40 \mu \mathrm{l}$ \\
$0.0032 \mathrm{ng} / \mu \mathrm{l}$ & $10 \mu \mathrm{l}$ of $0.016 \mathrm{ng} / \mu \mathrm{l}$ dilution & $40 \mu \mathrm{l}$ \\
\hline
\end{tabular}

Table 4. The standard dilution series for Plexor® HY System. [5]

\begin{tabular}{|lcc|}
\hline $\begin{array}{l}\text { Serial dilution of Control } \\
\text { DNA Z1 }\end{array}$ & Control DNA Zl & $\begin{array}{c}\text { QuantiTect Nucleic } \\
\text { Acid Dilution Buffer }\end{array}$ \\
\hline $20 \mathrm{ng} / \mu \mathrm{l}$ & Undiluted DNA & - \\
$5 \mathrm{ng} / \mu \mathrm{l}$ & $10 \mu \mathrm{l}$ & $30 \mu \mathrm{l}$ \\
$1.25 \mathrm{ng} / \mu \mathrm{l}$ & $10 \mu \mathrm{l}$ & $30 \mu \mathrm{l}$ \\
$0.3125 \mathrm{ng} / \mu \mathrm{l}$ & $10 \mu \mathrm{l}$ & $30 \mu \mathrm{l}$ \\
$0.078125 \mathrm{ng} / \mu \mathrm{l}$ & $10 \mu \mathrm{l}$ & $30 \mu \mathrm{l}$ \\
$0.01953125 \mathrm{ng} / \mu \mathrm{l}$ & $10 \mu \mathrm{l}$ & $30 \mu \mathrm{l}$ \\
$0.0048828125 \mathrm{ng} / \mu \mathrm{l}$ & $10 \mu \mathrm{l}$ & $30 \mu \mathrm{l}$ \\
\hline
\end{tabular}

Table 5. The standard dilution series for Investigator ${ }^{\circledR}$ Quantiplex HYres. [20]

\subsection{Quantifiler® Trio Quantification Kit}

The Quantifiler ${ }^{\circledR}$ Trio Quantification Kit (lot\# 1511018), reactions were prepared according to the protocol: 8uL of Quantifiler ${ }^{\circledR}$ Trio Primer Mix and 10uL of Quantifiler® THP PCR Reaction Mix for each sample was used to calculate the total volume of master mix. Then $18 \mathrm{uL}$ of master mix was added to each appropriate well in a 96-well reaction plate and $2 \mathrm{uL}$ of either sample, standard, or control for a total of $20 \mathrm{uL}$. The plate was sealed with an optical adhesive cover. The Applied Biosystems ${ }^{\mathrm{TM}} 7500$ Real-Time PCR instrument was used with the following cycling parameters: hold at $95^{\circ} \mathrm{C}$ for 2 minutes, then 40 cycles of $95^{\circ} \mathrm{C}$ for 9 seconds 
to $50^{\circ} \mathrm{C}$ for 30 seconds. Data was analyzed in the HID Real-Time PCR Analysis Software according to the protocol.

\subsection{Plexor® HY System}

The Plexor ${ }^{\circledR}$ HY System (lot\# 0000194319), reactions were prepared according to the protocol: 10uL of Plexor® HY 2X Master Mix, 7uL of amplification grade water, and 1uL of Plexor ${ }^{\circledR}$ HY 20X Primer/IPC Mix for each sample was used to calculate the total volume of master mix. Then $18 \mathrm{uL}$ of master mix was added to each appropriate well in a 96-well reaction plate and $2 \mathrm{uL}$ of either sample, standard, or control for a total of $20 \mathrm{uL}$. The plate was sealed with an optical adhesive cover. The Applied Biosystems TM 7500 Real-Time PCR instrument was used with the following cycling parameters: hold at $95^{\circ} \mathrm{C}$ for 2 minutes, then 38 cycles of $95^{\circ} \mathrm{C}$ for 5 seconds to $60^{\circ} \mathrm{C}$ for 35 seconds, followed by the "Dissociation Function" default setting. Data was analyzed in the Plexor ${ }^{\circledR}$ Analysis Software-Forensics according to the protocol.

\subsection{Investigator ${ }^{\circledR}$ Quantiplex HYres}

The Investigator ${ }^{\circledR}$ Quantiplex HYres (lot\# 154013504) reactions were prepared according to the protocol: 9uL of Reaction Mix YQ and 9uL of Primer Mix IC YQ for each sample was used to calculate the total volume of master mix. Then $18 \mathrm{uL}$ of master mix was added to each appropriate well in a 96-well reaction plate and $2 \mathrm{uL}$ of either sample, standard, or control for a total of $20 \mathrm{uL}$. The plate was sealed with an optical adhesive cover. The Applied Biosystems $^{\text {TM }} 7500$ Real-Time PCR instrument was used with following cycling parameters: hold at $95^{\circ} \mathrm{C}$ for 3 minutes, followed by 40 cycles of $95^{\circ} \mathrm{C}$ for 5 seconds to $60^{\circ} \mathrm{C}$ for 35 seconds. Data was analyzed in the HID Real-Time PCR Analysis Software according to the protocol.

\section{Results and Discussion}

\subsection{Serial Dilution Series using the NIST SRM 2372 Male DNA Component A}

The serial dilution series using the NIST SRM 2372 Male DNA Component A was performed to evaluate the accuracy of the various commercial quantification kits. The NIST serial dilution was defined by determining the concentration of each dilution using the standard 
curve created using the DNA standard that comes with each kit. The standard curve slope, yintercept, $\mathrm{R}^{2}$, and efficiency for the sample plate with the NIST dilutions can be seen in Table 6 .

The slope and fit of the data to the linear regression line $\left(\mathrm{R}^{2}\right)$ for each kit fell within the acceptable ranges provided by the manufacturers. This indicates that the standard curves were prepared properly and were reliable to compare unknown samples.

The log of the expected value versus the log of the measured values for the quantification kits can be seen in Figures 8, 9, and 10, and the r-squared and p-values in Table 7.

Table 6. Standard Curve Results for sample plate containing NIST dilutions.

\begin{tabular}{llllll} 
& & Slope & Y-intercept & R $^{\mathbf{2}}$ & Efficiency (\%) \\
\hline Quantifiler $\AA$ Trio & L-Auto & -3.52 & 25.336 & 0.997 & 92.36 \\
& S-Auto & -3.313 & 27.949 & 0.995 & 100.391 \\
& Male & -3.213 & 26.92 & 0.997 & 104.756 \\
\multirow{2}{*}{ Plexor® HY } & & & & 98.73 \\
& Human & -3.35 & 23.83 & 0.997 & 100.41 \\
& Male & -3.31 & 24.72 & 0.993 & 100.022 \\
Quantiplex HYres & Human & -3.321 & 25.524 & 0.994 & 100.97 \\
\hline
\end{tabular}





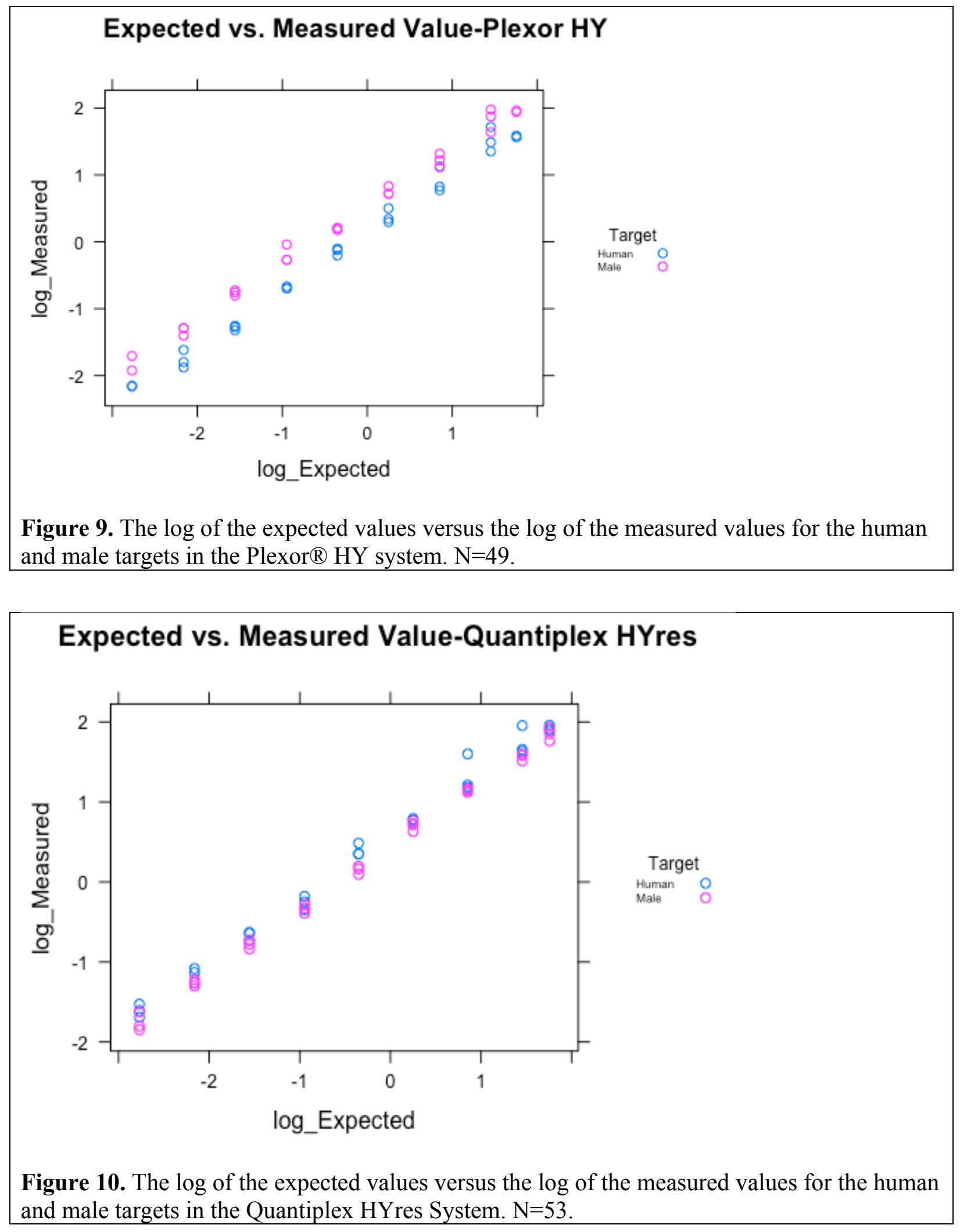
Table 7. NIST r-squared and p-value results for Quantifiler Trio, Plexor HY, and Quantiplex HYres quantification kits.

\begin{tabular}{|c|c|c|c|c|}
\hline 9 & Multiple $\mathbf{R}^{2}$ & Adjusted R ${ }^{2}$ & df & p-value \\
\hline Quantifiler ${ }^{\circledR}$ Trio & 0.9811 & 0.9808 & 79 & $2.20 \mathrm{E}-16$ \\
\hline Plexor® HY & 0.9683 & 0.9676 & 48 & $2.20 \mathrm{E}-16$ \\
\hline Quantiplex HYres & 0.9917 & 0.9916 & 52 & $2.20 \mathrm{E}-16$ \\
\hline
\end{tabular}

When compared the expected values of the NIST serial dilution to the obtained measured values for this experiment it was found that they are statistically significantly different (Table 7). Therefore, each quantification kit did not quantify the NIST standard DNA to the expected values. Each quantification kit had a p-value of 2.20E-16 and highly linear regression lines (rsquared values). The Plexor® HY system had the lowest r-squared values (multiple-0.9683, adjusted-0.9676), and the Quantiplex HYres system had the highest values (multiple-0.9917, adjusted 0.9916). This means that the Quantiplex HYres system data better fits the regression line and the expected values, as well as having less variation as a standard curve. However, the p-value still has to be considered and each kit was statistically significantly different.

The standard DNA solution used in the Quantiplex HYres kit is a mixture of male and female DNA, where in 1uL of sample there is 20ng of human DNA and 12.3ng of male DNA. Thus, during the analysis process the standard curves are evaluated using two different dilution series. The human target uses a four-fold dilution series with seven points starting at 20 to $0.0049 \mathrm{ng} / \mathrm{uL}$. The male target starts at 12.3 to $0.012 \mathrm{ng} / \mathrm{uL}$ with only 6 points. It is recommended not to use a seventh point in the male dilution series due to potential stochastic effects that could compromise the standard curve [20]. It is possible that because of the different standard curves utilized, that the specific male curve generated decreased the variability between the measured and expected values.

It is also possible that the standard curve at which we are determining these NIST SRM 2372 values is not as accurate as believed. In the DNA analysis software, each standard in the dilution series is given a quantity, regardless if it is that quantity or not. This could have a major effect on the reported results for the NIST SRM 2372 dilution series. There is the potential that the standard curve has been skewed to a higher fluorescence and lower quantities of DNA could be overlooked because they are appearing to be minute. 
If an external reference standard, such as the NIST SRM 2372, were to be used for the quantification kits for every time use, many serial dilutions and replicates should be performed to find where each concentration would lie in the standard curve for each particular kit and instrument. However, in this experiment the NIST SRM 2372 concentrations from the serial dilution did not quantify to the expected values.

\subsection{Commercial Kit DNA Standards Evaluation of Performance and Stability 4.2.1 Quantifiler® Trio DNA Quantification Kit}

The DNA standard that is supplied with the Quantifiler ${ }^{\circledR}$ Trio kit has a concentration of $100 \mathrm{ng} / \mathrm{uL}$. The serial dilution has five concentrations: Standard 1 is $50 \mathrm{ng} / \mathrm{uL}$, standard 2 is $5.0 \mathrm{ng} / \mathrm{uL}$, standard 3 is $0.50 \mathrm{ng} / \mathrm{uL}$, standard 4 is $0.05 \mathrm{ng} / \mathrm{uL}$, and standard 5 is $0.005 \mathrm{ng} / \mathrm{uL}$. The kit utilizes a large and small autosomal target as well as a male target. Therefore, a standard curve is constructed for each target. The average concentration for each standard over the three weeks for both low binding and regular microcentrifuge tubes were plotted for each target. The large autosomal, small autosomal, and male target plots can be seen in Figures 11, 12, and 13, respectively. Week one values were the oldest values, while week three values were the newest values.

The human target (Figure 11) values generally did not quantify at the expected values. The low binding tubes had higher concentrations in most cases than the regular tubes. Concentrations for both types of tubes, decreased over time. The regular microcentrifuge tubes in week one were actually closer to the expected values compared to the newest standard curve. The small target (Figure 12) concentrations for both tube types also decreased over time, with a spike in week two. Again, the values obtained were not close to the expected values. The small target is the primary quantification target and therefore should be the more accurate value. The male target (Figure 13) generally decreased over time except for the 50ng/uL concentration where it increased. The values obtained were also higher than the expected values. 


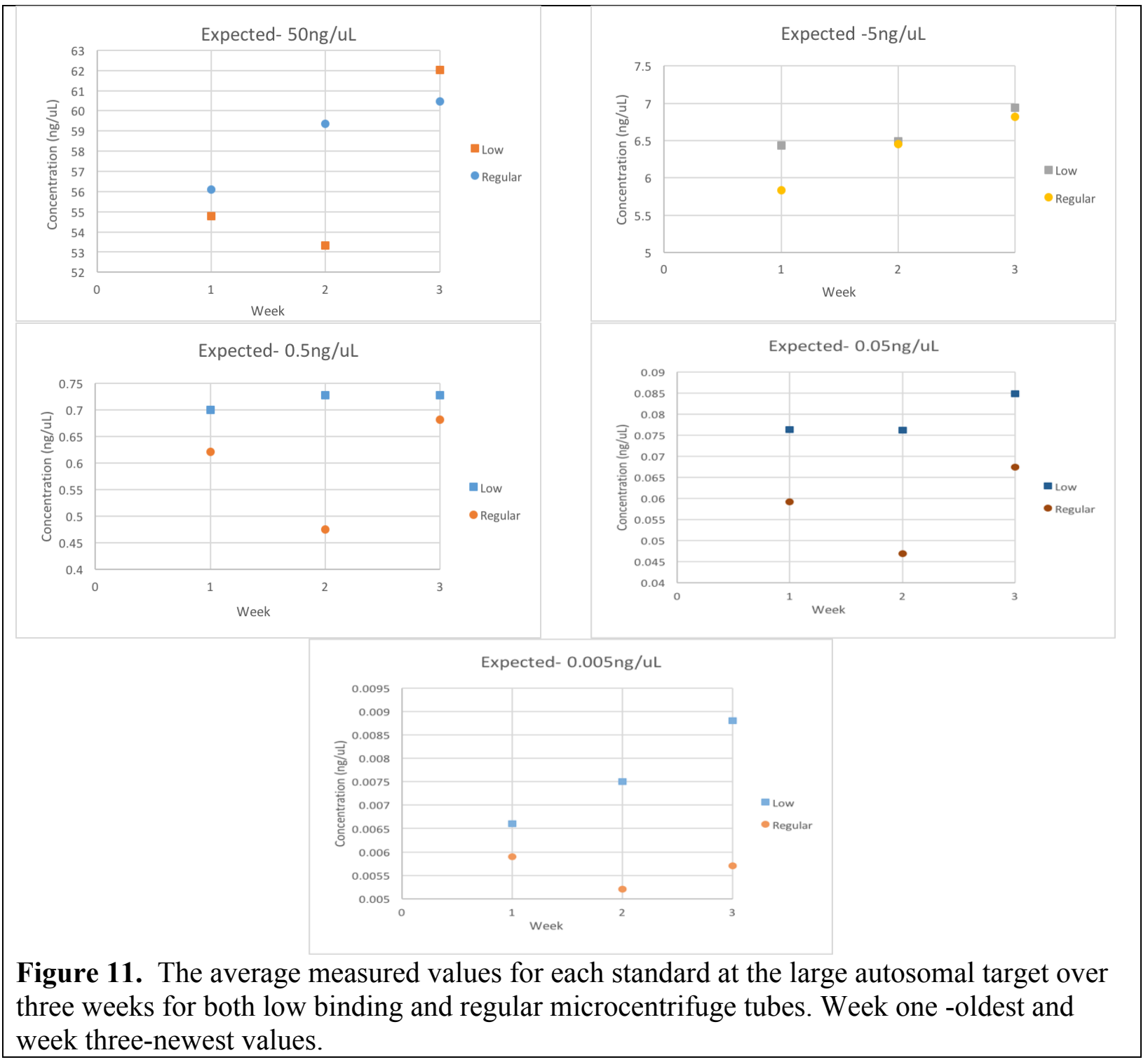




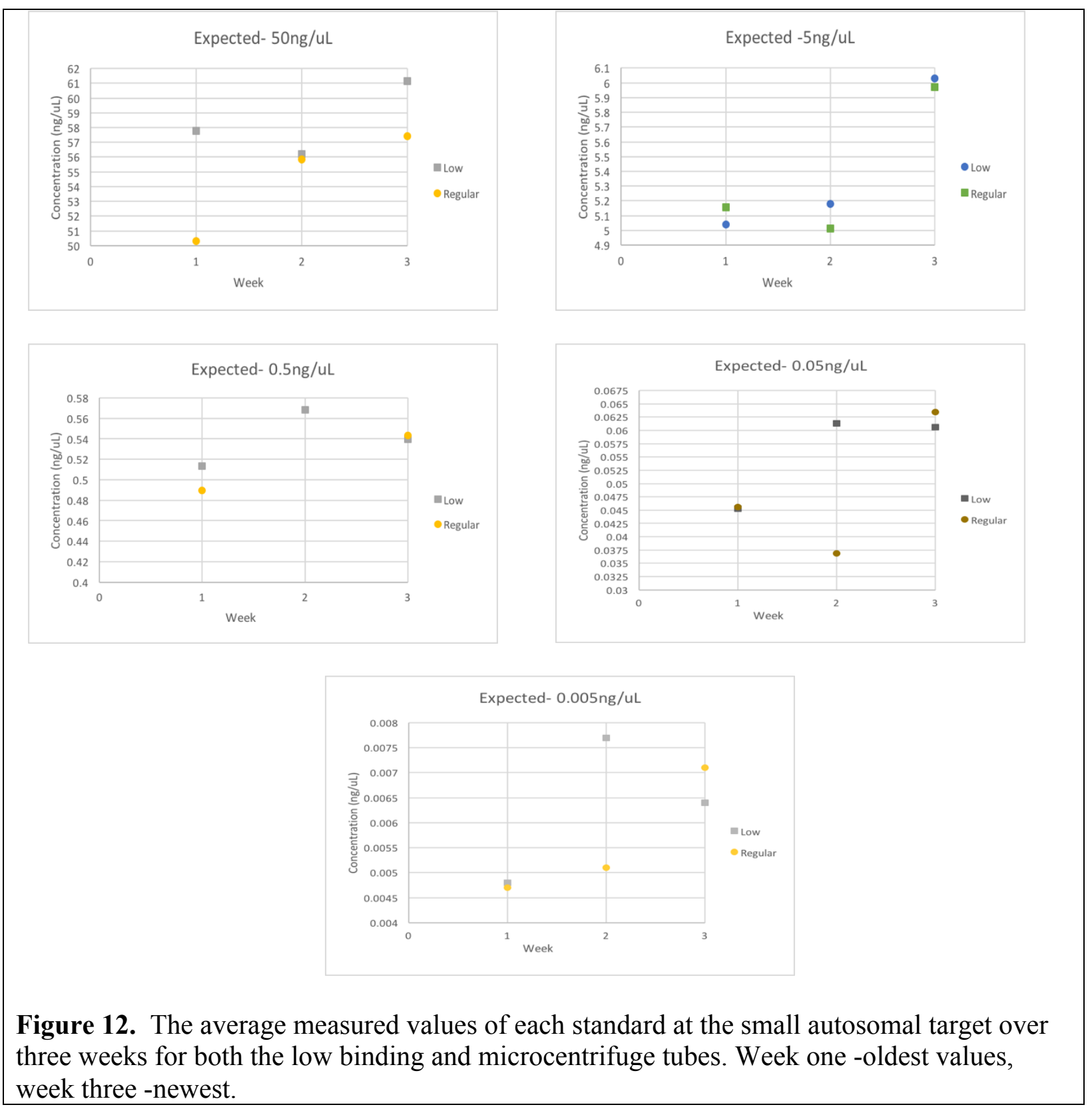




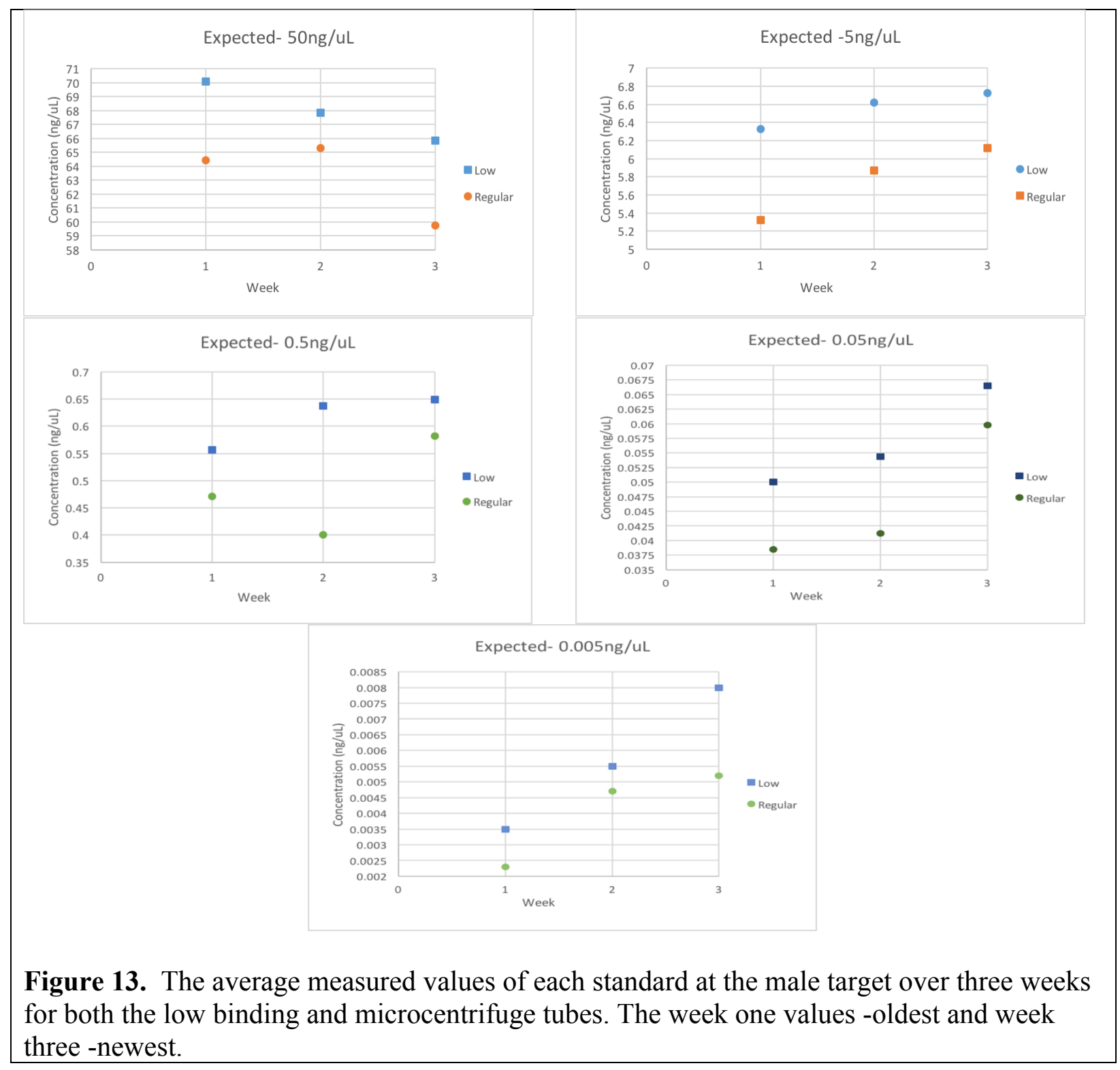

Additionally, the t-statistic, p-value and confidence interval for the comparison between low binding and regular microcentrifuge tubes at each standard dilution are tabulated in Table 8 . Assuming a p-value of 0.05 , a paired t-test was performed to see if the low binding tubes were effective at preventing DNA loss. The mean DNA lost ( $\mathrm{M}=2.2223, \mathrm{SD}, 4.2023, \mathrm{~N}=9)$ was not significantly greater than zero $(\mathrm{t}(8)=1.5865$, two-tail $\mathrm{p}=0.1513)$ providing no evidence that the low binding tubes are effective at 50ng/uL for preventing DNA loss. However, the 5, 0.5, 0.05, and $0.005 \mathrm{ng} / \mathrm{uL}$ had a mean difference significantly greater than zero (see Table 8 ), providing evidence that the low binding tubes are effective at these standards for preventing DNA loss. 
Table 8. The summary statistics for the Quantifiler ${ }^{\circledR}$ Trio kit. The mean difference between the low binding and regular microcentrifuge tubes for the total of three weeks.

\begin{tabular}{rccccc} 
Sample (ng/uL) & $\begin{array}{c}\text { Measured Mean } \\
\text { Difference }\end{array}$ & $\begin{array}{c}\text { SD of the } \\
\text { Difference }\end{array}$ & t-value & p-value & $\begin{array}{c}\text { CI of the } \\
\text { Difference }\end{array}$ \\
\hline 50 & 2.2223 & 4.2023 & 1.5865 & 0.1513 & 3.2302 \\
5 & 0.359 & 0.3888 & 2.7704 & 0.0243 & 0.2989 \\
0.5 & 0.1103 & 0.0958 & 3.4549 & 0.0086 & 0.0737 \\
0.05 & 0.0123 & 0.0106 & 3.6599 & 0.0064 & 0.0082 \\
0.005 & 0.0014 & 0.0013 & 3.2412 & 0.01186 & 0.001 \\
\hline
\end{tabular}

Two- tail $\mathrm{p}$-value $=0.05, \mathrm{~N}=9$ for each standard

Largely, it appears in this experiment that the DNA standard solution is not quantifying at the expected values for the standard curve. Thus, it is difficult to tell exactly how much of a change is occurring because the stock DNA solution is not quantifying at the expected starting concentration. Over time, the DNA concentrations are decreasing. However, at low concentrations of DNA, low binding tubes are significantly better at preventing DNA loss. In order to more accurately determine the concentration of an unknown sample, it would be recommended to determine the concentration of the standard DNA solution to be used with an external reference standard. It would also be recommended, when storing minute amount of DNA for long periods of time, a low binding microcentrifuge tube should be used to prevent DNA loss.

\subsubsection{Plexor ${ }^{\circledR}$ HY System}

The Plexor ${ }^{\circledR}$ HY Male Genomic DNA Standard has a concentration of 50ng/uL. The standard is serially diluted into seven concentrations: 50, 10, 2, 0.4, 0.08, 0.016, and $0.0032 \mathrm{ng} / \mathrm{uL}$. It is recommended by Promega not to store the diluted DNA solutions [5]. The low binding and regular tube concentrations are plotted over the three-week time period for both the human and male targets in Figures 14 and 15, respectively.

In the human target (Figure 14), from expected concentrations 2ng/uL and lower, the low binding tubes had greater concentrations than the regular tubes, and both types of tubes decreased in concentration over time. The expected concentrations of 50 and $10 \mathrm{ng} / \mathrm{uL}$, there was more variation between higher concentrations for either low binding or regular tubes. Generally, the low binding tubes were closer to the expected value, and the regular tubes were below the expected value. In the male target (Figure 15) at the expected $0.4 \mathrm{ng} / \mathrm{uL}$ standard and lower had 
greater concentrations in low binding tubes compared to the regular tubes. Additionally, the week two values appeared to be closer to the expected value than week three. The week three values should have been the closest to the expected value because it was the newest standard curve.

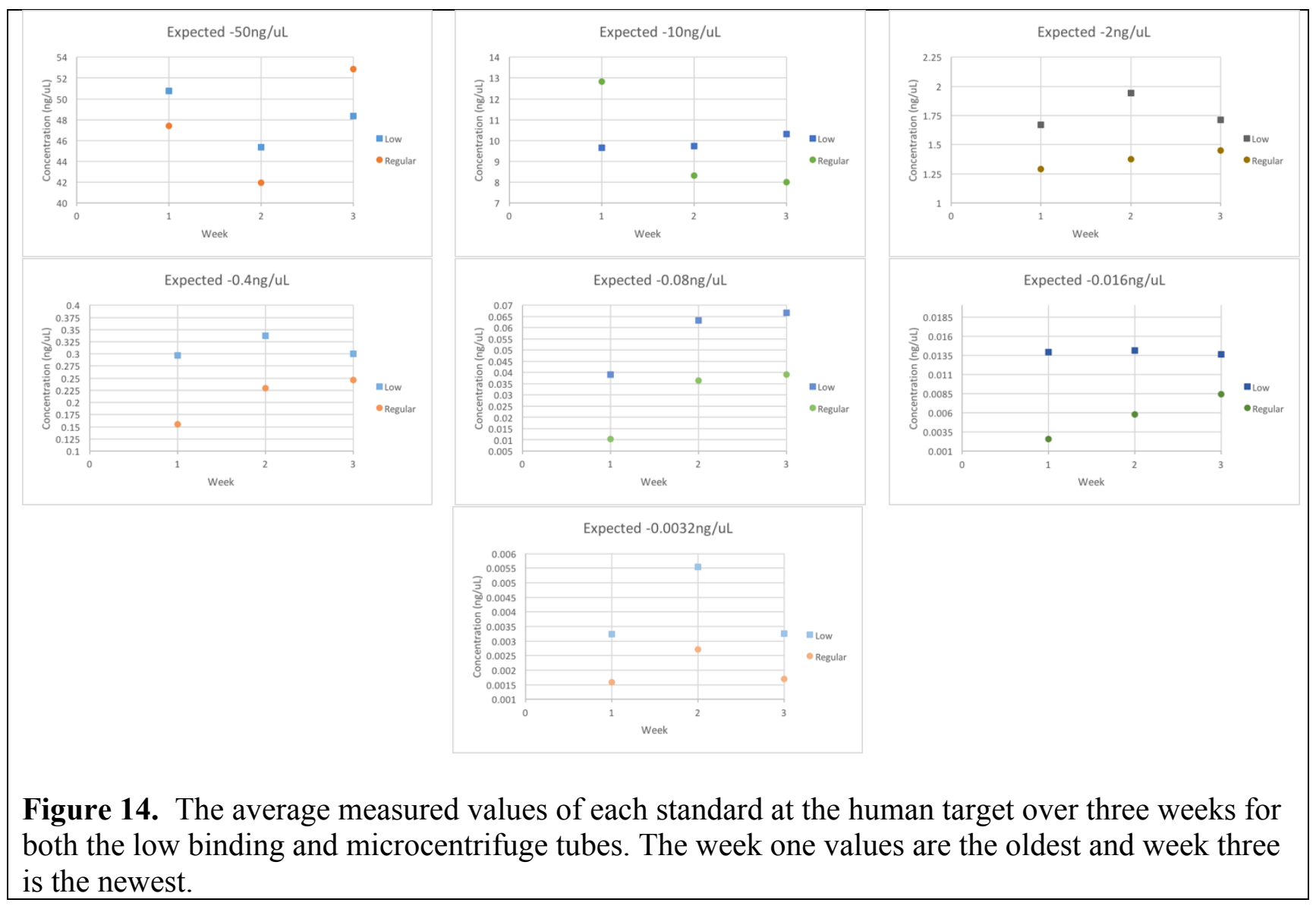



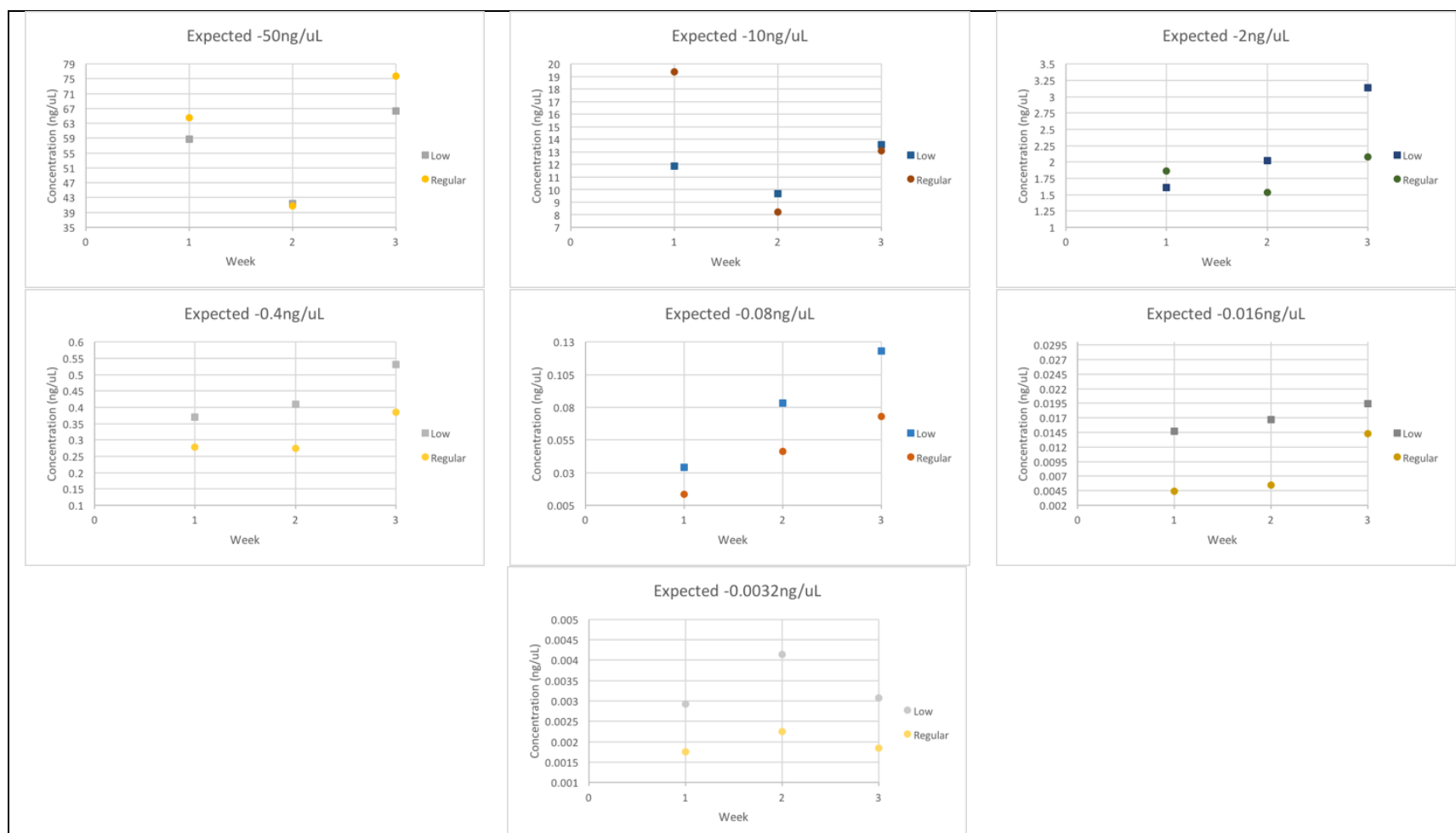

Figure 15. The average measured values of each standard at the male target over three weeks for both the low binding and microcentrifuge tubes. The week one values are the oldest and week three is the newest.

Additionally, the t-statistic, p-value and confidence interval for the comparison between low binding and regular microcentrifuge tubes at each standard dilution are tabulated in Table 9. Assuming a p-value of 0.05 , a paired t-test was performed to see if the low binding tubes were effective at preventing DNA loss.

The mean DNA lost $(\mathrm{M}=-2.0506, \mathrm{SD}, 5.311, \mathrm{~N}=6)$ was not significantly greater than zero $(\mathrm{t}(5)=-0.9458$, two-tail $\mathrm{p}=0.3877)$ providing no evidence that the low binding tubes are effective at 50ng/uL for preventing DNA loss. Additionally, the 10 and $2 \mathrm{ng} / \mathrm{uL}$ also provide no evidence that the low binding tubes are effective at preventing DNA loss. However, the 0.4, $0.08,0.016$, and $0.0032 \mathrm{ng} / \mathrm{uL}$ had a mean difference significantly greater than zero (see Table 9), providing evidence that the low binding tubes are effective at these standards for preventing DNA loss. 
Table 9. The summary statistics for the Plexor ${ }^{\circledR}$ HY kit. The mean difference between the low binding and regular microcentrifuge tubes for the total of three weeks.

\begin{tabular}{rccccc} 
Sample (ng/uL) & $\begin{array}{c}\text { Measured Mean } \\
\text { Difference }\end{array}$ & $\begin{array}{c}\text { SD of the } \\
\text { Difference }\end{array}$ & t-value & p-value & $\begin{array}{c}\text { CI of the } \\
\text { Difference }\end{array}$ \\
\hline 50 & -2.0506 & 5.311 & -0.9458 & 0.3877 & 5.5735 \\
10 & -0.8293 & 3.7917 & -0.5357 & 0.6151 & 3.9791 \\
2 & 0.4175 & 0.4263 & 2.3989 & 0.0617 & 0.4473 \\
0.4 & 0.1129 & 0.0355 & 7.7915 & 0.0006 & 0.0373 \\
0.08 & 0.0318 & 0.0103 & 7.5445 & 0.0006 & 0.0108 \\
0.016 & 0.0086 & 0.0029 & 7.3555 & 0.0007 & 0.003 \\
0.0032 & 0.0017 & 0.0006 & 7.008 & 0.0009 & 0.0006 \\
\hline
\end{tabular}

Two- tail $\mathrm{p}$-value $=0.05, \mathrm{~N}=6$ for each standard

It appears in this experiment that the DNA standard solution is not quantifying at the expected values for the standard curve. Like the Quantifiler ${ }^{\circledR}$ Trio kit, it is difficult to tell exactly how much of a change is occurring because the stock DNA solution is not quantifying at the expected starting concentration. Most of the time the DNA concentrations are decreasing at each standard. However, at low concentrations of DNA, low binding tubes are significantly better at preventing DNA loss.

In order to more accurately determine the concentration of an unknown sample using this kit, it would be recommended to determine the concentration of the standard DNA solution to be used with an external reference standard. Further experimentation with multiple lots of the DNA standard would also be recommended to see if this pattern continued.

\subsubsection{Investigator ${ }^{\circledR}$ Quantiplex HYres}

The DNA standard utilized in the Investigator ${ }^{\circledR}$ Quantiplex HYres kit is a mixture of male and female DNA to mimic a mixed sample. In $1 \mathrm{uL}$ there are 20ng of human DNA and $12.3 \mathrm{ng}$ of male DNA. The human and male targets use different standard curves. It is recommended that a seventh standard not be used in male determination because it is such a low quantity and it may have stochastic effects [20].

There was a great amount of variation over the time period between the low binding and regular tubes for each target. There is no general pattern for tube types over time for the human target (Figure 16). In some standards the concentration increased the following week, and in others it decreased. This indicates that this standard is not very stable for this portion of time. For 
the male target (Figure 17), there was a dramatic decline in quantity of DNA by week one. This also indicates that the DNA standard is not stable once it has been diluted to be used as a standard curve, regardless of tube type. However, in most cases the low binding tube sample had a slightly higher concentration than the regular tube samples, but nothing substantial.

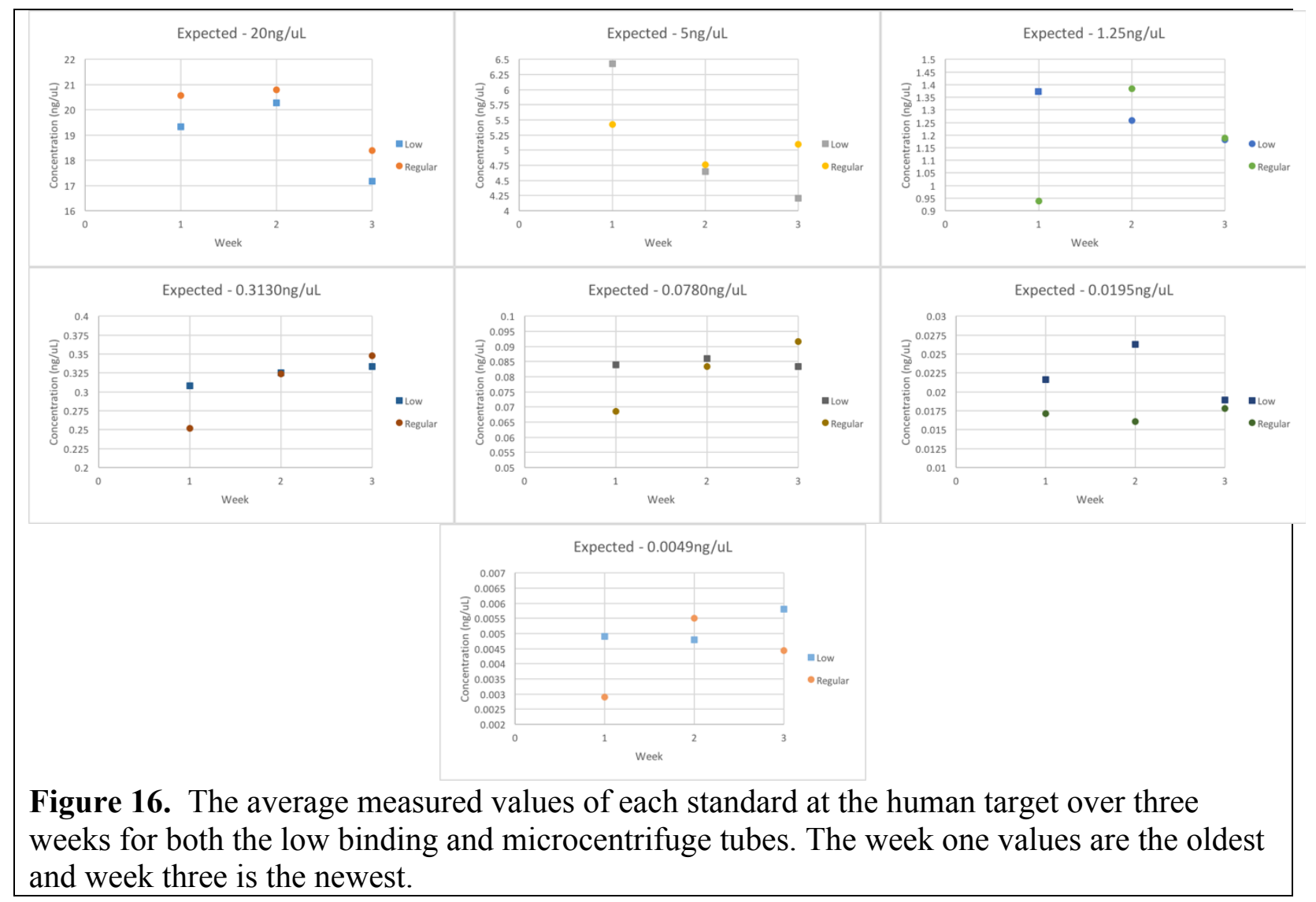




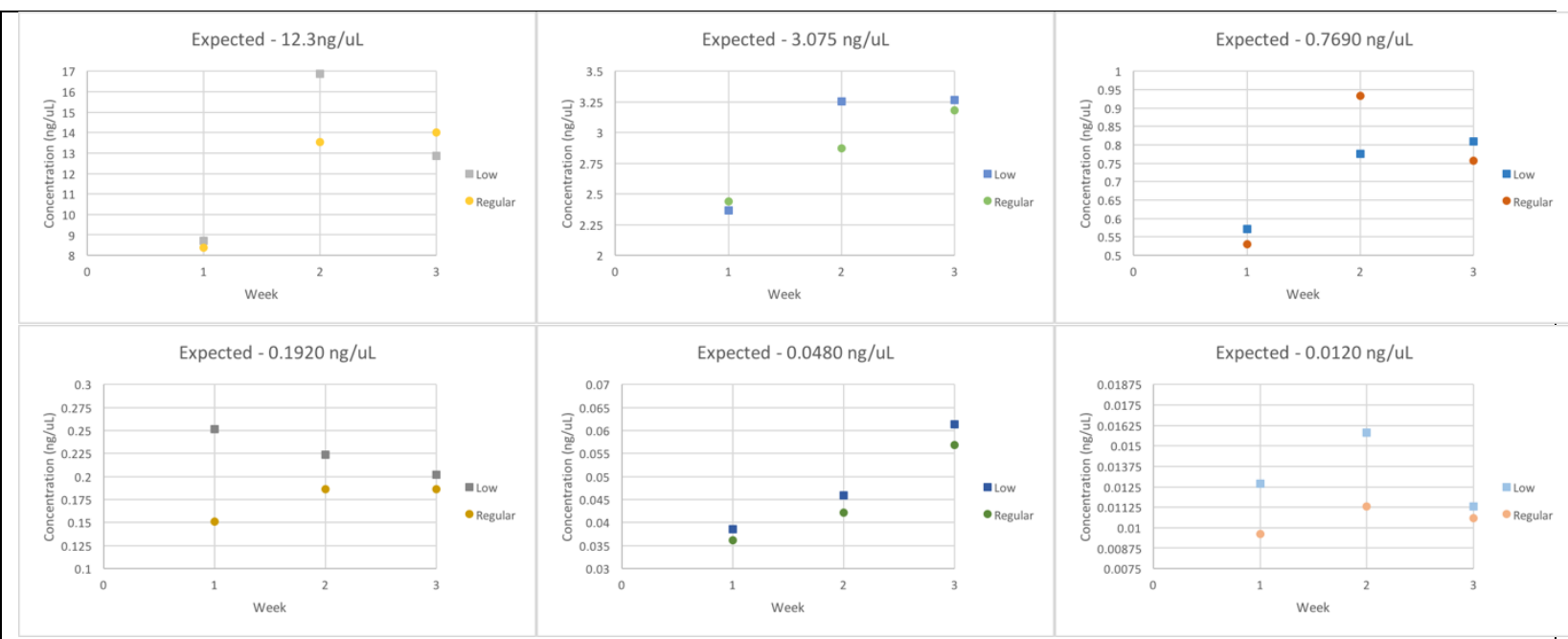

Figure 17. The average measured values of each standard at the male target over three weeks for both the low binding and microcentrifuge tubes. The week one values are the oldest and week three is the newest.

Like the Quantifiler ${ }^{\circledR}$ Trio and Plexor ${ }^{\circledR}$ HY kits, the t-statistic, p-value and confidence interval for the comparison between low binding and regular microcentrifuge tubes at each standard dilution are tabulated (Tables 10,11). Assuming a p-value of 0.05 , a paired t-test was performed to see if the low binding tubes were effective at preventing DNA loss. Two t-tests were performed separately on the human and male targets due to the different standard curves used to determine the concentration in the analysis software.

For the human target (Table 10), the mean DNA lost $(\mathrm{M}=-0.9979, \mathrm{SD}, 0.4158, \mathrm{~N}=3)$ was not significantly greater than zero $(\mathrm{t}(2)=-4.156$, two-tail $\mathrm{p}=0.0533)$ providing no evidence that the low binding tubes are effective at $20 \mathrm{ng} / \mathrm{uL}$ for preventing DNA loss. Additionally, the 5, $1.25,0.313,0.078,0.0195$, and $0.0049 \mathrm{ng} / \mathrm{uL}$ standards also provided no evidence that the low binding tubes are effective at preventing DNA loss (see Table 10).

This concludes that there is no significant difference between using the low binding over regular microcentrifuge tubes for preventing DNA loss when using the Quantiplex HYres DNA standard. The statistics obtained do reflect that variance and no overall general pattern was seen in Figures 16 and 17. 
Table 10. The summary statistics for the Quantiplex HYres human target. The mean difference between the low binding and regular microcentrifuge tubes for the total of three weeks.

\begin{tabular}{rccccc} 
Sample (ng/uL) & Measured Mean Difference & $\begin{array}{c}\text { SD of the } \\
\text { Difference }\end{array}$ & t-value & $\begin{array}{c}\text { CI of the } \\
\text { p-value }\end{array}$ & \begin{tabular}{c} 
Difference \\
\hline 20
\end{tabular} \\
5 & -0.9979 & 0.4158 & -4.156 & 0.0533 & 1.033 \\
1.25 & 0.0013 & 0.9527 & 0.0023 & 0.9983 & 2.3667 \\
0.313 & 0.0995 & 0.2947 & 0.5847 & 0.6179 & 0.732 \\
0.078 & 0.0142 & 0.0372 & 0.6614 & 0.5764 & 0.0923 \\
0.0195 & 0.0032 & 0.0118 & 0.4789 & 0.6792 & 0.0293 \\
0.0049 & 0.0053 & 0.0046 & 1.973 & 0.1872 & 0.0115 \\
\hline
\end{tabular}

Two- tail $\mathrm{p}$-value $=0.05, \mathrm{~N}=3$ for each standard

For the male target (Table 11), the mean DNA lost $(\mathrm{M}=0.8341, \mathrm{SD}, 2.292, \mathrm{~N}=3)$ was not significantly greater than zero $(\mathrm{t}(2)=0.6303$, two-tail $\mathrm{p}=0.5929)$ providing no evidence that the low binding tubes are effective at $12.3 \mathrm{ng} / \mathrm{uL}$ for preventing DNA loss. Additionally, the 3.07, $0.769,0.192$, and $0.012 \mathrm{ng} / \mathrm{uL}$ standards also provided no evidence that the low binding tubes are effective at preventing DNA loss (see Table 11). However, the $0.048 \mathrm{ng} / \mathrm{uL}$ had a mean difference significantly greater than zero $(\mathrm{M}=0.0036, \mathrm{SD}, 0.0010, \mathrm{~N}=3)$ was not significantly greater than zero $(\mathrm{t}(2)=6.0625$, two-tail $\mathrm{p}=0.0025)$ providing evidence that the low binding tubes was effective at this standard for preventing DNA loss.

Table 11. The summary statistics for the Quantiplex HYres male target. The mean difference between the low binding and regular microcentrifuge tubes for the total of three weeks.

\begin{tabular}{rccccc} 
Sample (ng/uL) & Measured Mean Difference & $\begin{array}{c}\text { SD of the } \\
\text { Difference }\end{array}$ & t-value & p-value & $\begin{array}{c}\text { CI of the } \\
\text { Difference }\end{array}$ \\
\hline 12.3 & 0.8341 & 2.292 & 0.6303 & 0.5929 & 5.6937 \\
3.07 & 0.1329 & 0.2333 & 0.9864 & 0.4279 & 0.5797 \\
0.769 & -0.0207 & 0.1172 & -0.3062 & 0.7884 & 0.291 \\
0.192 & 0.0511 & 0.0441 & 2.005 & 0.1827 & 0.1097 \\
0.048 & 0.0036 & 0.001 & 6.0625 & 0.0261 & 0.0025 \\
0.012 & 0.0028 & 0.0019 & 2.4935 & 0.1302 & 0.0048 \\
\hline
\end{tabular}

Two- tail $\mathrm{p}$-value $=0.05, \mathrm{~N}=3$ for each standard

With the exception of the $0.048 \mathrm{ng} / \mathrm{uL}$ standard, there was no evidence that the low binding tubes were effective at preventing DNA loss for this DNA standard solution. There is no significant difference between the low binding or regular microcentrifuge tubes. It would be 
recommended that additional studies be performed on this DNA standard to evaluate the variance seen between each standard dilution. Like the other quantification kits, an assessment of the DNA standard that is provided should be tested with an external reference standard to determine the actual concentration of the DNA standard for that specific lot and instrument.

\section{Conclusions}

In this experiment the Quantifiler ${ }^{\circledR}$ Trio Quantification Kit, the Plexor ${ }^{\circledR}$ HY system, and the Investigator ${ }^{\circledR}$ Quantiplex HYres kits, were evaluated to determine if an external reference standard would be suitable, as well as the performance and stability of their DNA standard control. A serial dilution created from the NIST SRM 2372 did not quantify at the expected values for any of the commercial kits. The obtained values were statistically significantly different from the expected values for each quantification kit. The Plexor® HY system had the lowest r-squared value, while the Quantiplex HYres had the highest r-squared value, indicating there was less variance in the values obtained when compared to the linear regression line.

If an external reference standard, such as the NIST SRM 2372, is to be used in any of these commercial kits, it is recommended that the standard be serially diluted and replicated many times to determine the range of values expected for a specific instrument and lot number. It is possible that the standard curve generated in each kit could be affecting the results of the NIST concentrations. Generally, the value reported by NIST for the SRM 2372, did not quantify to the expected values in any kit.

Additionally, the DNA standard solutions that are utilized in each system did not quantify at the expected values for the standard curve. In all three kits, the reported standard DNA solution concentrations were usually higher than the expected value and there was a large amount of variation. In lower concentrations of DNA, it was found that using a low binding microcentrifuge tube statistically prevented DNA loss for the Quantifiler ${ }^{\circledR}$ Trio and Plexor ${ }^{\circledR}$ HY kits. There were no significant evidence toward low binding tubes preventing DNA loss for the Quantiplex HYres DNA standard.

Generally, it would be recommended that when storing a DNA standard, it should be stored in a low binding microcentrifuge tube to prevent DNA loss, as they prevented DNA loss in two of the three DNA standard dilution series. A low binding tube would be highly recommended for lower concentrations of DNA because binding may occur in regular tubes. 
Overall, the DNA standards that are being utilized in each kit should be evaluated further before using them to create a standard curve. Theoretically, if a value is expected to be $50 \mathrm{ng} / \mathrm{uL}$ and it is actually quantifying at $60 \mathrm{ng} / \mathrm{uL}$, the fluorescence being emitted is for a $60 \mathrm{ng} / \mathrm{uL}$ sample and is being equated to $50 \mathrm{ng} / \mathrm{uL}$. This could be under or overestimating the unknown sample concentrations being determined from that standard curve. This could have impacted the values obtained for the time-trial of the serial dilutions for each kit, as well as, the NIST concentrations obtained.

In order for an external reference standard to be used in a crime laboratory it would have to be extensively tested on each instrument and over many lot numbers to develop a range of expected values for the standard. Moreover, the DNA standards being used in each kit should also be tested on each instrument and over different lot numbers, as the standards in this experiment did not quantify to the expected values.

Based on the observations in this experiment, no quantification kit out-performed the others in using an external reference standard to decrease inter- and intra- laboratory variability. The measured values for each kit were significantly different from the expected values. The Quantiplex HYres kit fit the linear regression line better than the other kits, but all the r-squared values were very high.

Additional testing should be conducted using the NIST SRM 2372; further studies include, analyzing additional lots of the standard, analyzing the standard via gel electrophoresis, or examining the 260/280 ratio on a spectrophotometer. These further studies could also be applied to the DNA standard that is included in each quantification kit to evaluate it before use.

Until both the DNA standard and the NIST SRM 2372 have been sufficiently evaluated for a particular lot number and particular instrument, the values should be taken as an estimate. The amplification process and further analyses should be conducted on unknown samples that have a very low quantification value, or no value at all. With the variance seen in this experiment between the expected value and the measured values, samples that are reporting no DNA present, may actually have DNA present and a DNA profile may be obtained. 


\section{References:}

[1] J. Butler, "DNA Quantitation," in Fundamentals of forensic DNA typing, Amsterdam, Academic Press/Elsevier, 2010, pp. 111-124.

[2] FBI, "Standards for Forensic DNA Testing Laboratories," 13 August 2011. [Online]. Available: https://www.fbi.gov/about-us/lab/biometric-analysis/codis/stds testlabs. [Accessed July 2016].

[3] M. Kline, D. Duewer, J. Travis, M. Smith, J. Redman, P. Vallone, A. Decker and J. Butler, "Production and certification of NIST Standard Reference Material 2372 Human DNA Quantitation Standard," Analytical and Bioanalytical Chemistry, no. 394, pp. 1183 $1192,2009$.

[4] C. J. Fregeau and N. Laurin, "The Qiagen Investigator® Quantiplex HYres as an alternative kit for DNA quantification," Forensic Science International: Genetics, no. 16, pp. 148-162, 2015.

[5] Promega, "Technical Manual: Plexor ${ }^{\circledR}$ HY System for the Applied Biosystems 7500 and 7500 FAST Real-Time PCR Systems," pp. 1-69, 2016.

[6] R. Kishore and C. Orrego, "Assessment by QPCR of DNA Binding to Plastic Microfuge Tubes," n.d.. [Online]. Available:

https://www.promega.com/ /media/files/resources/conference_proceedings/ishi_23/poste r_abstracts/53_poster.pdf. [Accessed 27 July 2015].

[7] Genetics Home Reference, "What is DNA?," 27 July 2015. [Online]. Available: http://ghr.nlm.nih.gov/handbook/basics/dna. [Accessed 29 July 2015].

[8] B. Alberts, A. Johnson, J. Lewis, M. Raff, K. Roberts and P. Walter, Molecular Biology of the Cell, 4th ed., New York: Garland Science, 2002.

[9] S. Clancy, "RNA Splicing: Introns, Exons and Spliceosome," 2008. [Online]. Available: http://www.nature.com/scitable/topicpage/rna-splicing-introns-exons-and-spliceosome12375. [Accessed July 2016].

[10] J. B. Reece, L. A. Urry, M. L. Cain, S. A. Wasserman, P. V. Minorsky and R. B. Jackson, Campbell Biology, 10th ed ed., Pearson, 2014.

[11] C. Cattaneo, K. Gelsthorpe and R. Sokol, "DNA Extraction Methods in Forensic DNA Analysis," in Encyclopedia of Analytical Chemistry Applications, Theory and Instrumentation, vol. 5, Tarzana, CA: John Wiley and Sons, LTD, 2006, pp. 4381-4402.

[12] W. W. Wilfinger, K. Mackey and P. Chomczynski, "Effect of pH and Ionic Strength on the Spectro-photometric Assessment of Nucleic Acid Purity," BioTechniques, vol. 3, no. 22, pp. 474-481, 1997. 
[13] J. Nicklas and E. Buel, "Quantification of DNA in forensic samples," Analytical and Bioanalytical Chemistry, pp. 1160-1167, 2003.

[14] Life Technologies, "Ethidium Bromide (EtBr) Dye for DNA and RNA Detection," 2015. [Online]. Available: https:/www.lifetechnologies.com/us/en/home/life-science/dna-rnapurification-analysis/nucleic-acid-gel-electrophoresis/dna-stains/etbr.html. [Accessed July 2016].

[15] J. Anderson, "Quantification of DNA by Slot-Blot Analysis," Forensic DNA Profiling Protocols, pp. 33-38, 1998.

[16] Applied Biosystems, "Real-Time PCR vs. Traditional PCR," Support: Tutorials, pp. 1-15, n.d.

[17] Life Technologies, "Quantifiler® HP and Trio DNA Quantification Kits User Guide," pp. $1-110,2015$.

[18] T. Förster, "Intermolecular energy migration and fluorescence," Analytical Physics, no. 2, pp. 55-75, 1948.

[19] I. Afonina, M. Zivarts, I. Kutyavin and e. al., "Efficient priming of PCR with short oligonucleotides conjugated to a minor groove binder," Nucleic Acids Res., no. 25, pp. 2657-2660, 1997.

[20] Qiagen, "Investigator® Quantiplex HYres Handbook," pp. 1-74, 2015.

[21] CoreGenomics, "Core Genomics," 18 March 2014. [Online]. Available: http://coregenomics.blogspot.com/2014/03/how-long-can-you-store-your-ngs.html. [Accessed July 2015].

[22] C. Gaillard and F. Strauss, "Avoiding adsorption of DNA to polypropylene tubes and denaturation of short DNA fragments," Technical Tips Online, pp. 63-65, n.d..

[23] M. Kline, D. Duewer, J. Redman and J. Butler, "Results from the NIST 2004 DNA Quantitation Study," Journal of Forensic Sciences, no. 3, pp. 1-8, 2005.

[24] L. Lewis, M. Robson, Y. Vecherkina, C. Ji and G. Beall, "Interference with spectrophotometric analysis of nucleic acids and proteins by leaching of chemicals from plastic tubes," BioTechniques, vol. 48, no. 4, pp. 297-302, 2010.

[25] Sigma-Aldrich ${ }^{\circledR}$, "Corning ${ }^{\circledR}$ CoStar ${ }^{\circledR}$ low binding microcentrifuge tubes," 2016. [Online]. Available: http://www.sigmaaldrich.com/catalog/product/sigma/cls3207?lang=en\&region=US. [Accessed July 2016]. 
[26] Sigma-Aldrich ${ }^{\circledR}$, "Eppendorf® LoBind microcentrifuge tubes," 2016. [Online]. Available:

http://www.sigmaaldrich.com/catalog/product/sigma/cls3207?lang=en\&region=US. [Accessed July 2016].

[27] USA Scientific $\AA$, "1.5 ml low adhesion microcentrifuge tube natural," 2016. [Online]. Available: http://www.usascientific.com/1.5-ml-low-adhesion-tube.aspx. [Accessed July 2016].

[28] D. Sarkar, "Lattice: Multivariate Data Visualization with R," Springer, 2008. [Online]. Available: http://lmdvr.r-forge.r-project.org. [Accessed July 2016]. 